


\title{
A Great Wall? \\ Migration, Political Socialisation and Political \\ Participation among Chinese in New Zealand
}

\author{
By
}

Ameera Clayton

A thesis

Submitted in fulfilment for the degree of

Master of Arts in Political Science

School of History, Philosophy, Political Science

\& International Relations

Victoria University of Wellington

2016 


\section{Abstract}

Chinese political participation is low by comparison with other migrant and ethnic groups despite high socioeconomic status. This suggests that other barriers to participation are present among this group. This study examines how pre- and post-migration political socialisation affect the electoral participation of Chinese in New Zealand. Fifteen one-on-one, in-depth interviews allowed me to consider the relationship between both length of residence and socialisation in a democratic versus non-democratic regime and electoral participation among this sample. In this case, analysis of each participant's migration and political participation experiences revealed no correlation between either length of residence and socialisation in a democratic versus non-democratic regime and electoral participation, although it highlighted the significance of demographic factors such as age and life-cycle, and social capital and political interest for electoral participation. Few studies have focused on Chinese migrant political participation specifically in New Zealand and even fewer on the subject of Chinese electoral participation. However, understanding what drives and inhibits electoral participation among this group is both important for the development of New Zealand's Asia-Pacific identity and ultimately as an indicator of the health of democracy in New Zealand. 


\section{Acknowledgments}

Firstly, I want to thank Dr Kate McMillan and Dr Fiona Barker, for the wealth of feedback, suggestions and direction. Their efforts were hugely instrumental for the development of this thesis and for the improvement of my skills as a researcher and writer. I would also like to express my thanks to the School of History, Philosophy, Political Science and International Relations.

Thank you also to The Electoral Commission, for the award of the Electoral Commission Suffrage Scholarship. Without the scholarship this thesis would most likely not exist.

A special thanks goes to my fifteen participants, and to those who put me in touch with my participants, who took time out of their lives to talk to me and shared personal experiences regarding their migration history and political participation, and ultimately provided me with my findings.

My gratitude goes to my officemates Sam and Johnny who encouraged focused study and provided timely distractions. Thank you also to my two proof readers, who offered two fresh pairs of eyes and invaluable feedback.

To my friends and family who are my support system and who unfailingly offered encouragement over the past year, thanks, I will keep you around. 


\section{Table of Contents}

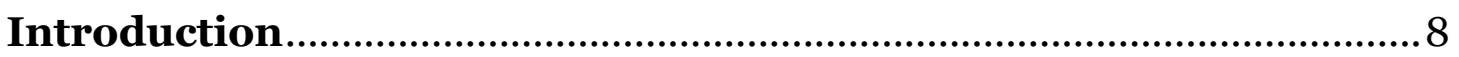

Chapter Two: Theoretical Framework................................................... 15

2.1 Theories of Political Participation ............................................................. 16

2.2 Theories of Migration Political Participation ............................................20

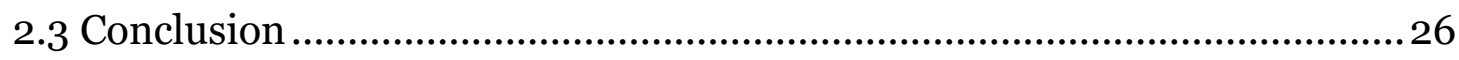

Chapter Three: Methods and Interviews ............................................ 28

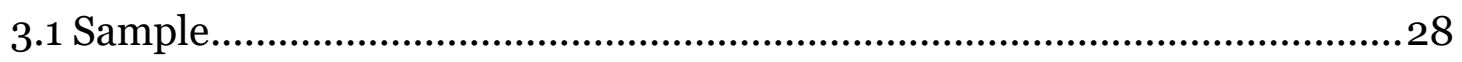

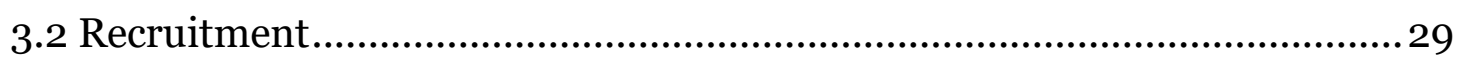

3.3 Variables and Interviews.......................................................................

3.4 Methodological Limitations ..................................................................... 32

3.5 Political Regime Classification …………………………........................34

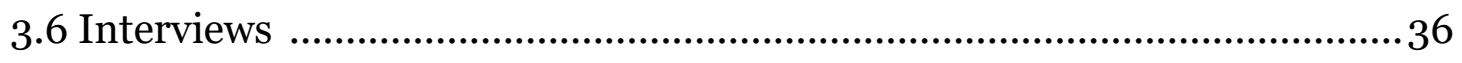

I. $1^{\text {st }}$ Generation Migrants ........................................................................ 38

II. 1.5 Generation Migrants ...................................................................... 43

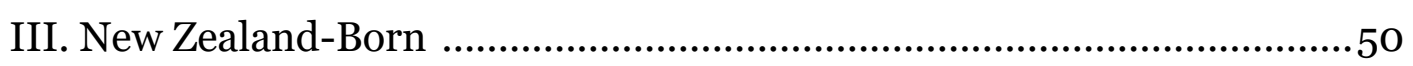

3.7 Summary …….................................................................................... 56

Chapter Four: Findings and Implications .................................58

4.1 Acculturation: Length of Residence …………………............................ 59

4.2 National Origin: Socialisation in a Democratic versus Non-democratic

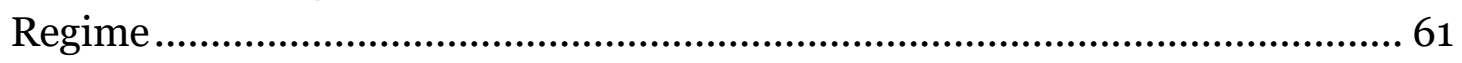

4.3 Political Interest and Social Networks: A Relationship of Mutual Influence .66

Conclusion ............................................................................ 75

Appendix 1: Participant Information........................................... 79

Appendix 2: Interview Questions ............................................ 81

Bibliography ..............................................................................88

Table 1: Participant Information ............................................ 37 


\section{Introduction}

In this thesis I ask how pre- and post-migration socialisation ${ }^{1}$ affects the electoral participation of ethnically Chinese ${ }^{2}$ migrants in New Zealand. We know that Chinese vote at lower levels than the majority and other ethnic populations both overseas and in New Zealand (Kuerban, 2005; Park, 2006; Tossutti, 2005). 3 Typically, Chinese communities in Western democracies, in particular recent Chinese migrants, have the resources associated with high levels of political participation, such as high socioeconomic status, yet they participate at low levels (Bevelander \& Pendakur, 2009; Jedwab, 2006; Lapp, 1999; Park, 2006; Tossutti, 2005; White et al., 2006). ${ }^{4}$ Research seeking to explain Chinese political participation has begun with this puzzle and asks, why is this the case?

A plethora of research exists on the numerous drivers of political participation 5 and specifically electoral participation (For example Putnam, 2001; Rosenstone, 1993; Verba \& Nie, 1972). Similarly, there is a wide range of research conducted on the drivers of, and barriers to, migrant political participation, examining both international and New Zealand cases (Bevelander \& Pendakur, 2009; Bilodeau, McAllister, \& Kanji, 2010; Park, 2006; Wong, Lien, \& Conway, 2005). However, there is a dearth of literature on the subject of both Chinese migrant electoral participation and 1.5 generation migrant electoral participation, especially in New Zealand. Buck

\footnotetext{
${ }^{1}$ See Chapter Two for a definition of political socialisation.

2 I define my usage of 'Chinese' later in this chapter.

3 Kuerban's (2005) U.S. study found that Chinese turnout at significantly lower levels than Filipinos, Vietnamese and Asian Indians. Tosutti's (2005) study also showed Chinese had the lowest turnout of all ethnic groups in a case study of Chinese Canadian electoral participation. Similarly, Park (2006) found in her New Zealand case study, that Chinese were less likely to participate, both electorally and non-electorally, than Pakeha.

4 High levels of resources yet low levels of participation among Chinese are further reinforced in the case of Chinese migrants in New Zealand who are viewed as a "model minority", as "unobtrusive, law-abiding, and undemanding - a largely middle class, welleducated, and low-profile group" ( $\mathrm{Ng}, 2001)$.

5 In this study, when I refer to political participation I adopt Verba's definition of political participation as an "activity that has the intent or effect of influencing government action - either directly by affecting the making or implementation of public policy or indirectly by influencing the selection of people who make those policies" (1995, p. 38, italics in original). More specifically, in this study electoral participation refers to the acts of enrolling to vote and casting a vote in a national election.
} 
(2009) is the only study thus far to focus on political participation of Asian 1.5 generation migrants in New Zealand.

Prominent theories emerging from the literature on migrant political participation identify length of residence and socialisation in a democratic versus non-democratic regime as significant variables determining electoral participation. These are yet to be tested in New Zealand among Chinese. Therefore, with this study I aim to contribute to the research on political participation of migrants and minorities in New Zealand by examining the significance of length of residence and political socialisation on levels of electoral participation. Moreover, my objective is to add to the wider international literature on migrant and minority political participation.

The contribution of studies in the field of migrant and minority political engagement and participation has been significant, yet most of these studies focus on the participation of Asian migrants in the United States and Canada (for example Aoki \& Nakanishi, 2001; Kuerban, 2005). Research into Chinese political participation is often explored within a broader Asian pan-ethnic identity (Aoki \& Nakanishi, 2001; Lien, 1994; J. S. Wong et al., 2005) or as part of a study focusing on several different Asian ethnicities (Buck, 2009; Oh \& Min, 2011; Park, 20066). Comparative case studies have their benefits of course, though single case studies allow for greater depth of research and analysis (Hopkin, 2010).7 There are markedly few studies on Chinese political participation conducted outside of the United States and Canada, understandably so as these two countries have large populations and large migrant and ethnic minority populations. It is important to increase the body of research on Chinese political participation to include the experiences of Chinese migrants in countries beyond the United States and Canada. The

6 Park's (2006) thesis is unique in that it is the first to systematically document contributing factors for Asian political participation in New Zealand. Much of the literature on Asian migrant political participation looks mainly at cases in Canada and the United States, and has a broad focus on the pan-ethnic Asian identity which we know to be both ethnically and demographically heterogeneous. Park's (2006) New Zealand study goes further, concentrating specifically on Chinese and Korean ethnic groups.

7 Regarding the comparative method, Hopkin (2010) stated that when one explanation is offered for an event, there may be other viable explanations which have not yet been considered or even revealed. Use of the comparative method can settle this. If the results are mirrored between cases this confirms the findings of the single case study, though if the results from each case differ this is an indication that other explanations should be explored. 
New Zealand case study presented here provides findings that add comparative value to current international debates about the levels of, and reasons for electoral participation among Chinese.

The size of New Zealand's Chinese population makes this group ripe for study. According to New Zealand Census data, those identifying as Chinese increased by 40.5 per cent between 2001 and 2006, and 16.2 per cent between 2006 and 2013. ${ }^{8}$ Migrants and ethnic minorities constitute a significant proportion of the New Zealand population: migrants constitute 25.2 per cent of the population; 11.9 per cent of the population identify as Asian; and the Chinese are the largest Asian ethnic group in New Zealand. 9

Between 2011 and 2012 of those accepted for New Zealand residency 13 per cent were from the People's Republic of China (China hereafter) in particular, the majority of which entered, and still do currently, using the Skilled Migrant Category (SMC). Many Chinese migrants also gain entry to New Zealand on student visas. Between 2010 and 2014, Chinese nationals comprised an average of 9 per cent of residential approvals through the SMC and an average of 29 per cent of international students (Ministry of Business, Innovation \& Employment, 2014, pp. 3, 7), highlighting high levels of socioeconomic status among Chinese in New Zealand.

Given the large migrant and migrant-origin population, New Zealand politics cannot be defined or understood without reference to its minority groups (Park, 2006, p. 208). The degree of migrant and minority political participation is indicative of New Zealand's ability to cope with its increasingly diverse population. This is especially relevant for the New Zealand case, given that New Zealand Residents have the right to vote in elections regardless of New Zealand citizenship status. ${ }^{10}$ If certain sections of the voting public are

\footnotetext{
${ }^{8}$ Furthermore, census data revealed 30 per cent of New Zealand's Asian ethnic groups are aged between 20-34 years compared with 18 per cent of the total population and that those belonging to younger demographics identify with more ethnic groups compared with older demographics (Statistics New Zealand, 2014, p. 12).

9 Data from the 2013 New Zealand census demonstrates that Chinese remains the largest Asian ethnic group in New Zealand and has been since at least 2006 and 2001 (Statistics New Zealand, 2014).

${ }_{10}$ Since 1975, in order to be eligible to enrol to vote in New Zealand one must be "a New Zealand citizen or permanent resident and have lived in New Zealand continuously for one year or more at some point" (Electoral Commission, 2015).
} 
known to be regular non-voters, parties and governments will be less inclined to take their interests into account (Mulgan, 1997, p. 267). On a wider societal level, it is in all of our interest that all members of New Zealand society participate in politics, so as to ensure an effective democracy. It is therefore crucial that we investigate the various drivers of, and barriers to political participation among different migrant and ethnic groups.

As New Zealand asserts its Asia-Pacific identity, and strengthens its economic and political ties within the Asia-Pacific we will likely see more movement of people across borders in the region. Statistics New Zealand projects a 90 per cent chance that the Asian population in New Zealand will have more than doubled by 2038 , from 0.54 million as it was in 2013 to 1.26 million in 2038 (2016). Migration trends indicate China is the largest source country of New Zealand residential approvals, comprising 17 per cent of approvals at 2014 (MBIE, 2014). It is, therefore, imperative that we understand the difficulties that arise from settling into, and politically engaging in, another country, and make efforts to remove any barriers to this process. The New Zealand sociopolitical community will be richer for striving to achieve this goal.

In order to answer the question on the effects of pre- and post-migration socialisation on ethnically Chinese electoral participation in New Zealand I utilised two methods. This research combined secondary literature analysis and original data collection in the form of one-on-one, in-depth interviews with fifteen Chinese participants, aged between 18 and 35 years, occupied either as students or young professionals and living in New Zealand. This sample was broken down further into three smaller groups to test the effects of varying periods of residence for electoral participation. Five were $1^{\text {st }}$ generation migrants, having migrated ages 16 years and over; five were 1.5 generation ${ }^{11}$ migrants and five were New Zealand-born. Throughout this thesis Chinese refers to ethnic identification. This ethnic category can include Hong Kong Chinese, Malaysian Chinese, Singaporean Chinese, Chinese New

\footnotetext{
${ }^{11} 1.5$ generation migrants are those who migrate as children with their family, I define this category more clearly later in this chapter.
} 
Zealander and Chinese from Taiwan, as is the case for this sample.12 Where Chinese denotes nationality I will specify using the term Chinese national.

The majority of Chinese in New Zealand have links to at least one of three waves of immigration: the nineteenth century immigrants, the majority of whom migrated during the Otago gold rush; twentieth century, pre-1986, immigrants, some of whom were political refugees ${ }^{13}$; and the post-1986 immigrants, who arrived after the immigration reviews which widened immigrant selection, basing selection on merit and skill rather than national origin (Ip, 2015; Ng, 2001).14 Among my sample, $1^{\text {st }}$ generation and 1.5 generation participants, including the latter's parents, represent the third wave of Chinese migrants to New Zealand. The New Zealand-born participants have connections to both the second and third waves of Chinese migration to New Zealand.

1.5 generation migrant refers to those who migrated as children. The precise definition of this category varies across studies with some remaining vague and others defining the age bracket between 6 and 18 years of age (see Bartley \& Spoonley, 2008; Nakash, Nagar, Shoshani, Zubida, \& Harper, 2012). My selection of 1.5 generation migrants differs slightly. 1.5 generation interviewees in my study migrated between the age of 5 and 13 years. This excludes those who migrated between 13 and 16 years of age. I set such parameters for the purpose of reducing the differences in experience, where possible, because migrating as a child differs from migrating as a teenager and I wished to limit these potential effects on the results. As it stands, migrant youth are vulnerable since they are likely to suffer from loss of friends in their nation of origin, potential trauma from the settlement process and social exclusion during the post-migration experience (For example Nakash et al., 2012, p. 228). Such difficulties could be the case, more so, among teenagers compared with children as they are more likely to have formed closer

\footnotetext{
${ }^{12}$ Statistics New Zealand's methodology defines "ethnicity as the ethnic group or ethnic groups that people identify with or feel they belong to" (Statistics New Zealand, 2004).

${ }_{13}$ The vast majority of Chinese migrants during these two waves were Chinese nationals, 1986 immigration reviews led to increased Chinese migration but also from a range of countries including China, Hong Kong, Taiwan, Singapore and Malaysia.

${ }^{14}$ Migrants during the early- and mid-twentieth century were fewer due to poll taxes and other restrictions for potential Chinese migrants to New Zealand.
} 
attachments in their nation of origin and will be comparably more self-aware specifically in terms of how others perceive and even exclude them. Having participants of similar ages in this category helps in that they have experienced similar levels of political socialisation overall.

Since they comprise one third of the sample, Chinese 1.5 generation migrants constitute a key aspect of my research. This is not only because this group has not been widely covered in the literature but also because of the group's value in the examination of the effects of pre- and post-migration socialisation. Chinese as an ethnic group are also valuable for studying the effects of socialisation in a democratic versus non-democratic regime since Chinese have been long settled in many East Asian countries outside of China, some classified as democratic and others classified as non-democratic. Selecting my sample from $1^{\text {st }}$ generation migrant, 1.5 generation migrant and New Zealand-born, ethnically Chinese allows me to analyse the effects of length of residence and socialisation in a democratic versus non-democratic regime whilst simultaneously controlling for ethnic identity. I analysed the interviewees' migration and political participation experiences for any relationship between length of residence and socialisation in a democratic versus non-democratic regime for electoral participation and examined the implications of my findings for established theory.

The fifteen in-depth interviews contradicted explanations for electoral participation such as length of residence and socialisation in a democratic versus non-democratic regime. Instead, they revealed the significance of political interest, social networks and demographic factors such as age and especially life-cycle. Participants who were older and/or at relatively later stages of their life-cycle demonstrated a greater awareness and political interest. Greater political interest helped to form and develop social networks, and political interest (and political knowledge) was also reinforced by social networks. This suggests that among this young cohort (the group's average age is 25 years), demographic and social capital theories were more relevant for explaining their electoral participation than length of residence and socialisation in democratic versus non-democratic regime. However, for older participants migrant and ethnic identity appeared more significant for 
electoral participation than it did for the younger participants. This finding suggests that, among this group, as age increased and as people moved into adult-life they became more aware of their specific experiences pertaining to their migrant and/or ethnic minority status, by contrast to the general population, and how these, and political decision-making, could affect their lives, ultimately driving political mobilisation and participation.

The thesis is structured as follows: in the next chapter I discuss the importance of resource and mobilisation theory of political participation as well as specific theories of migrant political participation. From this discussion of the literature I extract my two main variables: length of residence and socialisation in a democratic versus non-democratic regime. In Chapter Three I outline my research methodology and present the data from my fifteen one-on-one, in-depth interviews. Chapter Four details the findings of this research and suggests their implications. A concluding chapter discusses the limitations of the findings and scope for future research. 


\section{Theoretical Framework}

In this chapter I firstly, present theory which has been used to explain migrant political participation and Chinese political participation specifically, and secondly, highlight the prominent theories relevant for this research in particular. Overall, in this chapter I seek to answer the question of what explains the levels of electoral participation among the general population and among migrants in particular. I focus on resource and mobilisation theories of political participation and discuss the relevance of theories of migrant political participation. People will vote if they can, if they want to and if they are asked (Brady, Verba, \& Schlozman, 1995, p. 271). Implicit in this assertion is the relevance of resource and mobilisation theories in explaining drivers for political participation, and specifically electoral participation (Brady et al., 1995; Rosenstone, 1993). People can vote if they have the resources and political mobilisation is a mode of 'asking' people to vote and encouraging a desire to vote.

The literature focuses on resource and mobilisation theories of political participation. Resource-based theories such as demographic and socioeconomic theories focus on the relationship between wanting to vote, being able to vote, and political participation. Mobilisation theory also considers the relationship between being asked to vote and political participation. Theories of migrant political participation are necessary to translate broader theories to the case of migrants specifically. Acculturation and national origin theories highlight two variables which I assess in the analysis of my fifteen interviews. These two variables are length of residence and socialisation in a democratic versus non-democratic regime.

This thesis does not rigorously test hypotheses of theories of political participation. Rather, I employed these theories to explore the relationship between migration, political socialisation and electoral participation among those in my sample, and to assess the effects of migration on the drivers for electoral participation. The relationship between migration and electoral participation can help to understand, and have implications for, the theories outlined below. Throughout this chapter I include discussion on each theory 
and its significance for the relationship between migration and electoral participation. Although this is not a hypothesis testing exercise, once I explain each relevant theory I posit what I expect to find in this study. In this chapter I outline the theories of political participation and specific theories of migrant political participation relevant for the thesis. Theories of political participation discussed in section 2.2 are important for understanding participation of both general and migrant populations; these include demographic, socioeconomic, social capital and mobilisation theories of political participation. More specific theories, however, are necessary for understanding drivers for migrant political participation (Park, 2006). Therefore section 2.3 includes a discussion of acculturation, national origin and identity theories of political participation. ${ }^{15}$

\subsection{Theories of Political Participation}

Demographic factors such as age and socioeconomic status are widely thought to impact political participation. Strands of this broad theory focus on resources and include the relationship between age and political participation as well as socioeconomic theories. Theories regarding age state that as individuals grow older and demonstrate greater investment in society in terms of home or property ownership, marriage and settlement, their propensity to vote increases accordingly because of their increased social and economic stake in the decisions made by governments (Leighley, 1995). Age is often used to test this theory because variables such as property ownership and settlement are positively associated with age and are easily measured. The effects of age on political participation in numerous studies have been statistically significant (for example Lien, 1994, p. 248; Maxwell, 2010). Whilst age has demonstrated influence this may be a result of socioeconomic status (SES) and social capital, which are accumulated with age, as I will discuss. In order to explore other variables further, I controlled for age by selecting participants between 18 and 35 years of age.

\footnotetext{
15 Throughout this chapter I refer to both political participation and electoral participation. The majority of the theories I discuss pertain to political participation more broadly, whereas my study focuses on electoral participation more specifically. Where specification is necessary in this chapter, I have used the term electoral participation.
} 
Socioeconomic theory is well-established in the political participation literature. This theory identifies a positive relationship between SES and political participation. Greater access to time, money and education increases the likelihood of electoral participation compared with those of lower SES (Brady et al., 1995; Mayer, 2011; Park, 2006, p. 22; Quintelier, 2009; Verba \& Nie, 1972). One of the mechanisms implicit in this explanation is that SES results in levels of knowledge and civic skills necessary to foster political participation more broadly (Gimpe, Lay, \& Schuknecht, 2003; Rolfe, 2004).

Conversely, there is also evidence that shows high participation among lower socioeconomic groups (Zullo, 2008) and low participation among higher socioeconomic groups (Cho, 1999; Cho, Gimpel, \& Wu, 2006a; Uhlaner, Cain, \& Kiewiet, 1989). Among Asian migrants for example, SES does not always result in higher participation (Cho, 1999; Cho, et al., 2006a). Whilst the skills necessary for political participation may come with age and education, without the corresponding socialisation to foster strong beliefs and interest in democratic ideals and behaviour they will not translate into higher participation as projected (Cho, 1999, p. 1153). Political interest is significant in this explanation as it is employed as an indicator of political engagement (J. S. Wong et al., 2005, p. 553). Political interest differs from self-interest propagated by rational choice theory which states that the decision to vote is based upon a calculation of possible costs weighed against the possible benefits of the act of voting (Blais, 2000; Goode, 1997). Moreover, a lack of interest was also identified as the second central reason for not voting in the 2014 New Zealand national election, with 27 per cent of non-voters selecting this as their reason was not voting (TNS New Zealand, 2014, p. 13). Evidence suggests the relationship between SES and political participation may be mediated by other variables as I will discuss. Due to the lack of consensus on the effects of SES on electoral participation I sought to control for this by controlling for education. Hence, all participants are either in the process of, or have carried out, some form of tertiary education, which I discuss further in Chapter Three. 
Migrants may have high SES, as is the case with many Chinese and Chinese migrants, in the form of education and be occupied as middle-class earners with corresponding income, but the difficulties associated with settling into a new country may detract from the benefits associated with high SES such as increased knowledge and time. Nakash et al. (2012) highlight the difficulties associated with migration and the settlement process. They focus specifically on young migrants who can be negatively affected by the loss of connections in their nation of origin and experience social exclusion. However, these experiences can also be the case among adult migrants which can hinder settlement. Furthermore, Park (2006) stresses the importance of acculturation for self-esteem, which I will discuss further in this chapter in section 2.2 .

Social capital theory of political participation is based upon the value of social networks and their significance for political participation (Berger, Galonska, \& Koopmans, 2004; Fennema \& Tillie, 1999; D. Jacobs, Phalet, \& Swyngedouw, 2004; Putnam, 2001, pp. 18-19). Originally coined by L.J. Hanifan in 1916 to argue the importance of community, social capital increases upon coming into contact with others (Putnam, 2001, p. 19). Research indicates a positive relationship between social capital and electoral participation (Armingeon \& Schädel, 2015; Cho, Gimpel, \& Dyck, 2006b; Putnam, 2001). This relationship is based on the argument that individuals without the resources to inform themselves and, ultimately, make the decision to participate electorally derive political cues from others within their social networks who have comparably greater access to resources such as time and political knowledge. For Armingeon \& Schädel (2015) these cues are derived from political elites within political parties and other organisations (who do have the time and resources to inform themselves), though social capital can also be extracted from smaller networks such as peer groups and family. Since social capital is an inherently complex and contested concept I will refer to social networks specifically.

Social networks have also been found to discourage political interest, engagement and participation. The socialising effects of social networks have been linked with both political mobilisation and political de-mobilisation (Cho 
et al., 2006b; Eggert \& Giugni, 2010; Lem, 2010). Cho et al., (2006b) found the socialising effects, specifically of neighbours, were linked to political mobilisations, although they were also associated with political demobilisation. The contrast of findings relating to the effects of social capital, in particular social networks, on political participations directs us to the conclusion that social networks alone do not encourage political integration, engagement or participation. The nature of these social networks are equally as important for determining political participation.

After 1916, social capital was employed in research independently by several scholars throughout the twentieth century. It has been used in studies which characterised club memberships; praised neighbourliness within the twentieth century metropolis; underpinned the value of social and economic resources derived from social networks; and returned to Hanifan's original definition, highlighting the role of social networks for education (Bourdieau, 1983; Coleman, 1988; J. Jacobs, 1961; Loury, 1977; Seeley, Sim, \& Loosley, 1956). What these studies share is the significance they place upon social networks in their discussions of social capital. Social networks including family, peer groups and organisations such as clubs, workplaces, unions and political groups are significant for explaining the potential effects of both length of residence and socialisation in a democratic versus non-democratic regime on electoral participation, as I will elaborate in the following section. The aim of my research is not to explicitly test the effects of social networks for electoral participation, though social networks were important for explaining the relationship between length of residence, and socialisation in a democratic versus non-democratic regime and electoral participation as I communicate in this section.

Political mobilisation is widely accepted and acknowledged within the literature to encourage both electoral and non-electoral forms of political participation amongst both general and migrant populations (See Armingeon \& Schädel, 2015; Kriesi, 2008; Lapp, 1999; Rosenstone, 1993; Uhlaner et al., 1989). Political mobilisation can take the form of being directly asked to vote, or participate, by a fellow member of a political organisation or from other social networks. Political elites and organisations target and seek to mobilise 
different groups within society. Political elites and institutions can make it easier or harder for certain groups and individuals to participate (Park 2006). Mobilisation can also be indirect, and can occur when an individual is provided with information which encourages their political interest. As a response from one activist in a study analysing the mobilisation efforts of Latin Americans in the UK indicated, "It is out of necessity that people get organised: 'they are stealing my salary, they are underpaying me, they are sacking me without justification, they are violating my rights', [and] this is why people get organised. If people had it all they wouldn't organise" (Però, 2008, p. 82).

The main criticism of mobilisation theory asks what real influence strangers can have upon individuals and groups and why people would change their behaviour in response to strangers' efforts (Whiteley \& Seyd, 2002, p. 51), purporting, instead, that the decision to participate is largely an internal one. However, Kriesi's (2008) study highlighted the role of political elites and collective actors for the democratic process. Political organisations and elites capitalise on identity, which can be politically mobilised, leading to participation in electoral or non-electoral forms, as I will discuss further in section 2.3. For instance the British Chinese Project, an organisation seeking social and political engagement amongst the British Chinese population, is comprised of British Chinese active amongst the wider community (British Chinese Project, 2014). As with social networks I did not analyse my interviews for any relationship between mobilisation and electoral participation, though it was necessary to outline this theory of participation to explain the role of identity for electoral participation in section 2.3.

\subsection{Theories of Migrant Political Participation}

In this section I discuss theories of migrant political participation. Empirical evidence suggests a relationship between migration and political participation and electoral participation specifically. Migrants in general participate and turnout at lower levels than their general population counterparts (for example Bevelander \& Pendakur, 2009; Park, 2006; Tossutti, 2005; White et al., 2006). Additionally, literature calls for a focus on specifically migrant political participation in order to address these gaps 
found in participation among migrants. It is important to discuss broader theories of political participation as a basis for the following theories, however it is equally, if not more, important to include specific theories of migrant political participation. This is because migrants face a range of difficulties regarding settlement and integration that many autochthonous populations do not (Nakash et al., 2012, p. 228; Park, 2006).

Proponents of acculturation theory assert the importance of experience in a new political environment for immigrant political participation. Park states that "any new group of immigrants needs to acquire the necessary language, knowledge, confidence, and qualifications to enter the political arena of the host country" (Park, 2006, p. 26). Acculturation is the process by which these necessary attributes are gained by new migrants (Lien, 1994). Broadly speaking, this suggests length of residence is a significant variable for electoral participation. Of residents, those who spend longer and receive their education in the country in question are more likely to participate in the corresponding political sphere (Park, 2006; J. S. Wong et al., 2005, p. 562). The argument is that as an individual spends longer in a community, their opportunities to form and develop social networks increase and they are more likely to develop country-specific political knowledge, political interest and both a social and economic stake in society, ultimately increasing the chances of electoral participation. Other measures of acculturation such as English language skills, 'overall satisfaction', citizenship and 'feeling settled' have been found to be statistically significant, but for electoral enrolment specifically (Henderson, 2013). In selection of my sample in the New Zealand case, I accounted for the language measure ${ }^{16}$ whilst the other measures were beyond the scope of this study.

Research has also found acculturated migrants still have difficulties participating politically (Michelson, 2003; Park, 2006). Acculturation is also affected by political context and culture. When combined with a political culture of mistrust in government and cynicism, acculturation can have a corrosive effect on political participation (Michelson, 2003). Michelson's

\footnotetext{
${ }^{16}$ All participants have high levels of English proficiency as discussed further in Chapter Three.
} 
(2003) study looked at the levels of political trust in the United States, specifically among Latinos of Mexican descent, and found as they became more exposed to and integrated into mainstream American culture and became more aware of racism and discrimination they became more pessimistic about the American government, and as a result, less trusting. Research such as Abramson \& Aldrich's (1982) which suggests the positive relationship between political trust, belief in government responsiveness and political participation links Michelson's (2003) findings to political participation. ${ }^{17}$ There remains a lack of consensus as to which way acculturation theory affects migrant political participation. Whether it serves to encourage or discourage political engagement and participation is still debated. What the research on both sides of this argument do agree on, however, is the influence acculturation has upon political participation.

Acculturation theory of migrant political participation demonstrates the significance of post-migration socialisation or the nature of acculturation, for electoral participation, though there is a lack of consensus within the literature regarding its specific effect on migrant electoral participation. For the purposes of this study I extracted length of residence as a variable to investigate in my interviews. ${ }^{18}$ Three groups with varying lengths of residence have been selected for my sample. Based on research stating a positive relationship between length of residence and political participation I would expect $1^{\text {st }}$ generation migrant participants to participate the least, 1.5 generation migrants to participate more but less than New Zealand-born participants, whom I expect to participate the most. Whilst the $1^{\text {st }}$ generation migrants have spent time forming new social networks once they have migrated, the 1.5 generation migrants and New Zealand-born have the advantage of a longer period of residence and may already have wellestablished social networks, which can help to increase country specific

\footnotetext{
17 Perception of the government and other institutions as significant for political participation is another theme throughout the literature. Research demonstrates that negative perception of government and government responsiveness can act as a barrier to political participation (Abramson \& Aldrich, 1982; Henn \& Foard, 2012; Kriesi, 2008).

${ }^{18}$ Length of residence was a variable employed by Park (2006) as part of her assessment of the relationship between acculturation and political participation. The survey results demonstrated that Chinese and Korean New Zealander's "newness" was a significant barrier to their political participation.
} 
political knowledge, and foster an interest in political issues, ultimately increasing the likelihood of electoral participation.

National origin or the political regime in which an individual is politically socialised is further argued to influence political participation. Pre-migration socialisation in authoritarian regime correlates with low voter turnout among immigrants (Bueker, 2005; Ramakrishnan, 2005). Proposed explanations highlight that the socialisation received in an authoritarian regime differs greatly from that received in a democratic regime and inhibits migrant adaptation to the demands of democratic regimes, such as electoral participation. This is based on the expectation that socialisation in a democratic regime encourages political discussion within social networks and even encourages open criticism of the political elites. This in turn encourages acquisition of political knowledge and political interest because more people are openly talking about political issues. Vice versa, it is expected that socialisation in a non-democratic regime discourages people from openly discussing political issues within their social networks. Discussion of political issues is often used to measure political interest, a central aspect of political integration (Eggert \& Giugni, 2010, pp. 177, 185).

More recent studies, however, have shown socialisation in a democratic regime does not guarantee high levels of political participation among migrants (for example Park, 2006, p. 51). In almost all political activities, Park (2006) found Koreans had the lowest participation rates despite high SES and the fact they would have experienced Korea's transition to democratic status. Research indicates experience in an authoritarian regime can discourage engagement in non-electoral forms of participation such as petition signing and protesting (Bilodeau, 2008), because these forms of participation openly criticise the political regime and are even illegal in authoritarian regimes such as China. A more recent study, carried out by Bilodeau, McAllister, \& Kanji (2010) found no negative correlation between socialisation in an authoritarian regime and electoral participation. Whilst their findings support the argument that socialisation in an authoritarian regime can influence immigrants' adaptation to a democratic regime, it is not, in and of itself, an obstacle for electoral participation. Due to a lack of 
consensus in the literature regarding its influence, it is important to examine socialisation experiences further in a New Zealand case study of Chinese electoral participation.

In order to understand the effects of socialisation in a democratic versus nondemocratic regime on migrant electoral participation I selected a sample of young Chinese who had experienced their political socialisation in a range of countries with different political regimes. These participants had experienced their political socialisation in one of six countries: Singapore, China, Taiwan, Hong Kong, Japan or New Zealand. Examining the relationship, if any, between each participant's national origin and their electoral participation will help in the assessment of whether or not socialisation in a democratic versus non-democratic regime is relevant for electoral participation in New Zealand.

Transnationalism ${ }^{19}$ is a phenomenon which is increasingly discussed in the context of migrant political participation. A characteristic of transnational migrants is their continued relations with their nation of origin in the form of sustained relationships: maintained business and property interests and even political participation in their nation of origin (Richman, 1992; Rios, 1992). Research into the effects of transnationalism on citizenship, settlement and a sense of belonging, and the effects of these, in turn, on electoral enrolment and political participation suggest transnationalism may discourage settlement, and even political engagement and participation (Bartley, 2010; Bartley \& Spoonley, 2008; Henderson, 201320). One central line of reasoning behind this suggestion is that transmigrants may not have a strong attachment to any place and may simply be living simultaneously in both

19 Transnationalism and transnational identity is a concept gaining salience from the increasing mobility of people across the globe, enabled by rapid technological advancement in transport and communication. A shift in migration studies over the past two-three decades represents a growing influence of transnational identity is a necessary subject (Levitt \& Jaworsky, 2007). Confirmation of this can also been seen in growing regionalism and the rise of transnational political networks such as the European Union and Asia-Pacific Economic Cooperation, both of which are membered by their constituent national and transnational institutions.

${ }^{20}$ Henderson (2013) identified a positive relationship between both citizenship and a sense of belonging, and electoral enrolment, but no clear link between being settled and electoral enrolment. 
locations, neither absolutely here nor there, now or in the future (Glick Schiller \& Basch, 1995, p. 56).

Conversely, research also demonstrates the lack of any significant relationship between transnational identity and variables such as citizenship and sense of belonging which have been positively associated with political participation (Bueker, 2005; L. L. Wong, 2007). I would expect $1^{\text {st }}$ generation immigrants to exhibit characteristics of transnationalism, because they have more recently migrated and already had established lives in their nation of origin, including social networks. I also expect 1.5 generation immigrants to demonstrate characteristics of transnationalism because they may maintain relationships with extended family and peer groups in their nation of origin. However, I do not expect transnational relations or networks to significantly influence electoral participation of this sample and do not seek to explore this concept in any great depth in this research.

Identity theories of political participation are also employed to explain political participation of different migrant groups (for example Jacobs \& Tillie, 2004; Lien, 1994; Wong et al., 2005). Ethnic and pan-ethnic identity ${ }^{21}$ has been found to indirectly affect electoral participation because it provides a basis for mobilisation (Jacobs \& Tillie, 2004; Uhlaner et al., 1989; Wong et al., 2005). Greater internal ethnic engagement, increases the civic community score and the likelihood a group will be politically active (Jacobs \& Tillie, 2004, p. 422). An individual more engaged in their community, ethnic or otherwise, is more likely to form a strong identification with that community, which further increases the likelihood of being politically mobilised (J. S. Wong et al., 2005, p. 586). In the US case, Wong et al. (2005) found that belonging to an ethnic organisation and feeling a connection with others sharing the same ethnic background positively affected electoral and non-electoral forms of political participation. In order to focus on the two variables discussed previously, I controlled for identity by

${ }^{21}$ Pan-ethnicity is a term used to identify people and groups either originally from or inhabiting a broad region which usually encompasses various other ethnic groups. For example Park (2006) refers to "Asians" and "Asian-Americans" in her study. In Park's (2006) research she focuses on Chinese and Korean ethnic groups within these broad pan-ethnic identities however, they also include other South Asian ethnicities such as Indian, and South-East Asian identities such as Thai, Cambodian and Vietnamese. 
selecting a sample of individuals belonging to the same pan-ethnic Asian and Chinese ethnic group. Whilst I ensured all participants identify with the same ethnic groups, this does not necessarily provide any indication regarding the strength of this identification. Some participants may identify more with their self-identified ethnic identity than other participants. 


\subsection{Conclusion}

Among other variables, research analysing demographic theories of political participation focused on age and the socioeconomic indicator: education, both of which I controlled for, for the purposes of this study. A review of the literature suggests demographic and socioeconomic explanations of political participation are mediated by other variables such as social capital, specifically social networks, which are crucial for explaining theories of migrant political participation. In order to explore other variables in this research I controlled for age and education by selecting a sample of participants from within the age bracket of 18-35 years and those who were currently carrying out, or had completed, some form of tertiary education.

In sum, literature on electoral participation of Asians and specifically Chinese in Canada, the United States and New Zealand highlights the importance of acculturation and national origin as well as broader explanations such as demographic, socioeconomic and social capital factors. Research based on samples from the United States underpins the salience of acculturation and social capital theories for explaining political participation among Asian and Chinese populations (Lien, 1994, 2010). In a Canadian study, Lapp (1999) found variations in turnout among five ethnic communities in Montreal Chinese, Greek, Italian, Jewish and Portuguese were related to political culture within social networks. In a study of the effects of social capital for electoral participation among minorities in Canada, Bevelander \& Pendakur found that individuals identifying as Chinese were among those with lowest rate of electoral participation, though they attributed electoral participation largely to demographic, socioeconomic and social capital factors (2009, pp. $1414,1420)$.

Park (2006) and Buck (2009) are the two main studies in New Zealand focusing on the drivers of, and barriers to Chinese political participation. Both explore explanations for low participation among Chinese comparatively, alongside other Asian ethnic groups in New Zealand and in the United States. Buck's (2009) found that demographic factors such as age and life-style were more influential than migrant and ethnic backgrounds of her sample of 18-24 year olds. In Park's (2006) study the overall regression 
indicated that as length of residency increased so too would voter turnout and highlighted the positive influence of attitudes such as political interest for political participation.

A review of the literature on theories of migrant political participation reveals the significance of both length of residence and socialisation in a democratic versus non-democratic regime for electoral participation around which there is currently no consensus. The literature analysing both would benefit from their application in a New Zealand case study. In order to examine the effects of length of residence I have selected a sample of participants with varying lengths of residence. $1^{\text {st }}$ generation migrant participants migrated to New Zealand at the age of 16 years or over. 1.5 generation migrant participants migrated to New Zealand between the ages of 5 and 13 years old with their parents whilst New Zealand-born participants have been born in New Zealand and have since been resident in New Zealand. In order to traverse the effects of socialisation in a democratic versus non-democratic regime for electoral participation I recruited a sample of participants from a range of countries, some democratic and others non-democratic regimes. In section 3.5 of Chapter Three I discuss the regime classifications of each of the countries in which participants experience their socialisation. Overall, based on the existing literature I expected participants who had received their premigration political socialisation in a democratic regime to participate more, relative to their counterparts who had received their pre-migration socialisation in a non-democratic regime. 


\section{Methods and Interview Data}

In the following chapter I discuss my research methods and present my data derived from fifteen interviews with ethnically Chinese participants. In the first four sections of this chapter I outline my research methods. Firstly, I provide details on the composition of my sample. Secondly, I outline my recruitment methods. Thirdly, I detail how each interview ran and present the questions designed to investigate the variables discussed in Chapter Two. Fourthly, I explain the methodological limitations (namely researcher bias and the sample size), followed by how these could have affected the results; how I attempted to mitigate the effects; and ultimately the benefits of these perceived limitations. Table 1 illustrates the participant information including each participant's age; ethnic groups; their length of residence in New Zealand; country of birth; self-determined ethnic identity and whether or not they voted in 2014. In the subsequent sections of the chapter, I present the regime classifications of Singapore, China, Taiwan, Hong Kong, Japan and New Zealand, and the results from the $1^{\text {st }}$ generation migrant, 1.5 generation migrant and New Zealand-born Chinese participants.

\subsection{Sample}

This sample is comprised of: ethnically Chinese participants; either $1^{\text {st }}$ generation migrants, 1.5 generation migrants or New Zealand-born, 18-35 year olds, either students or young professionals. The $1^{\text {st }}$ generation migrant participants migrated at the age of 16 years and over. Individuals belonging to this group spent the majority, if not all, of their childhood outside of New Zealand. Their migration to New Zealand has been the result of their own personal choice rather than that of their parents, as is the case with 1.5 generation migrants. Their length of residence in New Zealand ranges between 3 and 10 years. 1.5 generation refers to those who have migrated to New Zealand between the ages of 5 and 13 years. Some of this group have been in New Zealand since primary or early secondary school. They have memories of their migration experience coupled with significant political socialisation in New Zealand. The parents of the New Zealand-born 
participants are $1^{\text {st }}$ generation immigrants or New Zealand-born children of other $1^{\text {st }}$ generation immigrants.

Throughout the presentation of the interviews I refer to each participant using a pseudonym. Any other names within the interviews themselves have also been changed in order to maintain the confidentiality of this study. In addition to accounting for age, ethnicity and education I have also accounted for language. Among migrants, language is often considered a barrier to political participation (Cho, 1999; Henderson, 2013; D. Jacobs, Phalet, \& Swyngedouw, 2004). To account for this variable, my sample is comprised of either native English speakers or those with high levels of English. For all New Zealand-born participants English was their first language. Aside from one participant, Ashleigh, all other participants for whom English was not a first language had studied in New Zealand beginning at either primary, secondary or tertiary level. This ensures all participants had English skills adequate enough so that language would not act as a barrier to their electoral participation. Language is therefore not considered a barrier to participation, enabling this thesis to explore and focus on other factors influencing participation.

\subsection{Recruitment}

To recruit interview participants I began by circulating information to organisations in both Wellington and Auckland in the form of posters and a participant information sheet (See Appendix 1). These were Chinese community groups in addition to sports groups and clubs at Wellington and Auckland universities. Koha ${ }^{22}$ was offered as part of the research with the aim of attracting participants who did not necessarily have prior interest in politics or political participation. These efforts resulted in the recruitment of the first eight participants, all living in Wellington. The remaining seven participants, also living in Wellington, were recruited either after a second circulation of information around universities and social media such as Facebook, or via snowballing. Once I had conducted an interview I asked participants to forward information to anyone they knew who also fit the criteria for my research. This included a participant's younger sister, the classmate of

${ }^{22}$ A donation in exchange for participation, in the form of a gift voucher. 
another participant, as well as four participants who I recruited via my own social network.

I experienced difficulties making contact with participants and especially so with those who did not participate politically, either electorally or otherwise, and with both 1.5 generation migrant Chinese and New Zealand-born Chinese. All $1^{\text {st }}$ generation participants and one 1.5 generation migrant were recruited from the first circulation. Two more 1.5 generation migrants were the result of the second circulation. The other two 1.5 generation participants and one New Zealand-born participant were recruited via snowballing. Four out of the five New Zealand participants were drawn from my own social network. Establishing contact with this demographic - students, young professionals, aged 18-35 years - was difficult. My experience recruiting my sample group may give some indication of why political participation, both electoral and non-electoral, among this age group is very low. These individuals are cementing their new lives having completed their education, have fewer social and economic investments in society than their senior counterparts and either have or make less time to spend on political engagement and participation (See Buck, 2009; Leighley, 1995; Lien, 1994; Maxwell, 2010).

\subsection{Variables and Interviews}

The interviews were conducted throughout August and September of 2015, between nine and twelve months after New Zealand's previous general election in September, 2014. It follows then, that the output variable be voter turnout in the 2014 election as it was the most current measure possible. This variable was observed via participants' responses to the question 'Did you vote in the past election and would you vote in the next election? Why or Why not?' An answer yes to the first part of this question also implied electoral enrolment, since you cannot vote without having first enrolled to vote. I examined the two input variables, length of residence and socialisation in a democratic versus non-democratic regime, by asking participants to tell me about their migration history. ${ }^{23}$ Length of residence was determined by how

\footnotetext{
23 For New Zealand-born participants I did not have to determine where they were socialised or how long they had been resident in New Zealand, as they were born in New Zealand and had been resident in New Zealand since.
} 
many years they had been in New Zealand for. Socialisation in a democratic versus non-democratic regime was discerned by participants telling me of their national origins and from analysis of Freedom House scores ranking freedom of each political regime in terms of electoral processes, political and civic rights, as I will discuss further in section 3.5.

In order to also analyse the basis of explanations for the effects of length of residence and socialisation in a democratic versus non-democratic regime on electoral participation, I asked participants about their levels of political interest and their social networks. Firstly, regarding political interest, this variable was measured in this research by participant responses to the question 'When was the last time you spoke to family or friends about a political issue?' Political interest has previously been explored by employing proxies such as talking about politics (See Berger et al., 2004; Fennema \& Tillie, 1999; D. Jacobs et al., 2004). A participant's level of political interest was indicated by the frequency of political discussions with friends and family which suggested a desire to discuss such issues, which is one measure of political interest. As some may be interested in political issues yet choose not to discuss them frequently with others I also measure political interest by responses to the question 'Where do you get your political news from?' Secondly, regarding social networks I asked: 'How often do you have contact with your family and friends? By what media?', 'Did your family and friends vote in the past election? Why? Why not?' and 'Are you a member of any groups ${ }^{24}$ ?' The aim of these questions was to analyse their responses against each participant's length of residence and whether they were socialised in a democratic or a non-democratic regime.

I utilised in-depth interviews as my central method of data collection because of its value for seeking information regarding individual experiences (migration and political socialisation) and identifying any relationship between these experiences and their demonstrated behaviour (electoral

24 If participants were initially unsure I would offer some examples, such as sports groups, cultural groups or party membership. 
participation). ${ }^{25}$ In-depth interviews are characterised by their use of a semistructured interview guide, establishing rapport with the interviewee, asking open questions and by the use of probing to encourage the interviewee to tell their story (Hennink, 2011, pp. 109-110; Wengraf, 2001). In the case of this research, in-depth interviews were useful for exploring migration and political socialisation experiences and determining how these affected their behaviour, in the form of electoral participation, specifically turning out to vote.

The interviews were between 30-60 minutes long and were recorded so they could later be transcribed. ${ }^{26}$ In order to explore my variables I constructed a series of questions, outlined above. The interview began with questions about their occupation, history of study and their migration history. Beginning with these questions allowed me to gain some background on the participant in addition to helping the participant feel comfortable answering questions, by starting with questions they could be confident in answering. The subsequent questions required a little more thought by the participant, asking them about their sources of political news and their history of political participation (both electoral and non-electoral). Appendix 2 lists the interview questions asked of each participant.

\subsection{Methodological Limitations}

There are three methodological limitations to consider prior to proceeding with the presentation of the interview data. The first is regarding the nature of the sample, in particular characteristics of four participants that do not quite fit the sample brief as I will explain. The second is the perceived limitation of sample size and the third limitation is researcher bias.

Neither Victoria nor Phoebe were eligible to vote at the time of the 2014 election. However, their responses were still valuable for exploring how preand post-migration socialisation affect political interest and social networks and the desire to participate. Ashleigh is the only participant not occupied as a student or young professional. At the time of the interview she was a part-time

\footnotetext{
25 I also employed secondary source analysis for identifying regime classifications for the countries in which my sample had experienced their pre-migration socialisation. In the case of the New Zealand-born participants pre-migration socialisation was not relevant. ${ }^{26}$ Wengraf (2001) identified the use of in-depth interviews to reveal narratives about people's lives and that these "stories" are often recorded for subsequent analysis.
} 
cleaner, though she was an English student prior to migrating from Taiwan. Carol did not migrate from Hong Kong, Taiwan, China, Singapore or Malaysia like the other participants and many other Chinese migrants to New Zealand. Instead, Carol migrated from Japan; her parents migrated to Japan from Hong Kong shortly after Carol was born but she and her parents have maintained regular contact with their extended family in Hong Kong in the form of phone calls and visits as I will highlight in the interview data. None of these perceived limitations, however, affected the results significantly as they were still interesting for comparing length of residence, socialisation in a democratic versus non-democratic regime with political interest and social networks, and, in the cases of Carol and Ashleigh, against electoral participation, as I will discuss further in the interview data section.

Furthermore, the relatively small sample of fifteen participants used for this study could be construed as a methodological limitation. As with the nature of the single case study, however, this small sample allowed me to focus more time on collecting and analysing the data gleaned from my fifteen respondents. This is a benefit McGrath, Butcher, Pickering, \& Smith attested to in their report on Asian communities in New Zealand: "Individual testimonies are an important and vital part of understanding migration, and drawing on migrants' stories, in a variety of forms, is becoming a key methodology in migration studies" (2005, p. 5). One-on-one interviews allowed a depth of analysis often not achieved via surveys. The semi-structured form of the interviews allowed me to derive participants' reasons for voting, or not voting, in their own words rather than them choosing from a set of pre-selected responses as is the case with many surveys.

Researcher bias is another factor for the interview and analysis process to consider. Being a 1.5 generation migrant myself and a visible minority, I have my own thoughts on the subject informed by my own experiences occupying this identification. Additionally, I knew four of the participants prior to the interviews which can prove both useful and problematic for the interview process and analysis. For the interview process, I found a previous relationship helpful in terms of ensuring the participant was comfortable with me, and answering my questions. However, it is also possible that, for fear of 
judgement of some kind, participants were more guarded in their answers to some, more personal, questions which may have been answered differently had the participant not known me previously. Overall, a previous relationship was beneficial as the establishment of a rapport and trust between the interviewee and the interviewer is one central characteristic of in-depth interviews (See Hennink, 2011; Wengraf, 2001). Additionally, both my previous thoughts on the subject and previous knowledge of some participants may have influenced the way I interpreted particular answers. In an effort to mitigate the effects of researcher bias I have included the interview questions in Appendix 2 and direct quotes from participants throughout the presentation of interview data and the subsequent chapter discussing the findings, where possible, rather than just my own interpretations.

\subsection{Political Context: Democratic and Undemocratic regimes}

Firstly, it is important to distinguish between non-democratic and democratic regimes. When it comes to classification, however, some regimes elude clear definitions. In this case, the countries in which some of these migrants experienced their pre-migration socialisation, the classification of the political regime is the subject of considerable debate. For the purposes of this thesis I have utilised the Freedom House classifications ${ }^{27}$.

Based upon the Freedom House freedom classifications combined with their electoral process scores each nation of origin was classified, for the purposes of this study, thusly: the PRC, Hong Kong and Singapore are defined as nondemocratic as their electoral process ratings were $0 / 12,3 / 12$ and 4/12 respectively. ${ }^{28}$ Taiwan, Malaysia ${ }^{29}$, New Zealand and Japan were classified as

\footnotetext{
27 These classifications were from a Freedom House report categorising countries' freedom status, political rights and civil liberties: freedomhouse.org/report/freedomworld-2016/table-scores and from the following reports on the political and electoral systems of each country:

freedomhouse.org/report/freedom-world/2015/china freedomhouse.org/report/freedom-world/2015/hong-kong freedomhouse.org/report/freedom-world/2015/malaysia freedomhouse.org/report/freedom-world/2015/new-zealand freedomhouse.org/report/freedom-world/2015/singapore freedomhouse.org/report/freedom-world/2015/taiwan freedomhouse.org/report/freedom-world/2015/japan ${ }^{28}$ With $\mathrm{O}$ being the worst score and 12 being the best possible score.
} 
democratic; Malaysia received an electoral process rating of 6/12 and Taiwan, New Zealand and Japan all scored 12/12. New Zealand has a representative democracy, a constitutional monarchy and is deemed "free" by Freedom House. Taiwan has been a representative democracy since its first Presidential election in 1996 and is classified as "free" by Freedom House. China is an authoritarian regime ruled by its only party, The Chinese Communist Party and is deemed "not free" by Freedom House. Japan has a bicameral national legislature and constitutional monarchy, serving as the ceremonial head of state, and is defined as "free" by Freedom House.

Hong Kong and Singapore were also given freedom classifications by Freedom House but since their classifications as democratic versus nondemocratic is contentious compared to New Zealand, Taiwan, Japan and China I analysed other sources to justify their regime classifications in this study.

Hong Kong is technically a region of China and considered "partly free" according to Freedom House standards of freedom based on political and civic liberties. In the 1980s, and prior to transfer in 1997, Britain introduced democratic reforms and a District Board and Legislative Council were created in 1981 and 1985 respectively. Boniface \& Alon (2010) align with explanations that Hong Kong's previous link to the West has influenced the movement toward democracy, and argue that the 1997 transfer has not diminished democratic governance that was in place with "voice and accountability" having actually improved. This notion is confirmed by comparing Freedom House's freedom scores between 2002 and 2015. The numeric freedom and civic liberties ratings had improved from 4 and 3 , respectively in 2002 to 3.5 and 2 in $2015.3^{30}$

Singapore's political regime can be characterised as a largely one-party democracy. Freedom House classifies it as "partly free"; similarly its internet

29 Malaysia's regime classification, similar to Singapore and Hong Kong, is not clear cut. However, I will not discuss Malaysia in great depth as only one New Zealand-born participant (Laurie) had strong connections with Malaysia. Since Laurie is New Zealandborn she has experienced all of her political socialisation in a democratic country. $3^{30}$ With this scoring system 1 is the best and 7 is the worst (Freedom House, 2015) https://freedomhouse.org/report/freedom-world/2015/hong-kong 
is classified as "partly free" whilst its press is deemed "not free". Singapore's electoral process score (4/12) may be marginally better than Hong Kong's (3/12) but overall the trend in the literature on Singapore's political regime is pessimistic regarding any democratic characteristics beyond elections which ensure preservation of the one-party system (Barr, 2014, p. 31).

New Zealand's political system is characterised by its representative parliamentary system and constitutional monarchy. National elections are held once every three years using the mixed-member proportional electoral system. Voters are granted two votes: one party vote and one vote for a candidate in their geographical electorate. The National Party and Labour Party are the two central political parties and occupy centre-right and centreleft positions, respectively, on the political spectrum. Several other special interest parties include the Green; ACT; Māori; New Zealand First; and United Future parties among others. The most recent election was September, 2014 in which a National-led government was elected into its third consecutive term (Freedom House, 2015). ${ }^{31}$

\subsection{Interviews}

In the following section I present each participant and key details from the interviews under the sub-sections: $1^{\text {st }}$ generation immigrant; 1.5 generation immigrant and New Zealand-born. For each participant I firstly outline where they experienced their pre-migration socialisation; how long they have been resident in New Zealand (specifically in the case of the $1^{\text {st }}$ and 1.5 generation migrants); their occupation; and whether or not they voted in the 2014 election and their occupation which are also found in Table 1. Secondly, I relay their reasons in their own words for voting; the sources through which they access their political news; how often they discuss political issues and which topics they discuss. Thirdly, I note their social networks: how often they are in contact with their friends and family; and any group membership they have.

\footnotetext{
${ }^{31}$ National formed the government after gaining support of confidence and supply from the Māori Party, ACT Party and United Future Party (Parliamentary Library, 2015). Information regarding New Zealand's political and electoral systems was also from the following report: freedomhouse.org/report/freedom-world/2015/new-zealand
} 


\begin{tabular}{|l|l|l|l|l|l|}
\hline Name & Age & Gender & $\begin{array}{l}\text { Voted in the } \\
\text { 2014 election }\end{array}$ & Eligible $^{22}$ & Birthplace \\
\hline
\end{tabular}

1st Generation

\begin{tabular}{|l|c|c|c|c|c|}
\hline Victoria & 19 & F & $\times$ & $\times$ & Singapore \\
\hline Phoebe & 27 & F & $\times$ & $\times 33$ & China \\
\hline Johnny & 25 & M & $\sqrt{ }$ & $\sqrt{ }$ & China \\
\hline Ashleigh & 34 & F & $\sqrt{ }$ & $\sqrt{ }$ & Taiwan \\
\hline Patrick & 34 & M & $\sqrt{ }$ & $\sqrt{ }$ & China \\
\hline
\end{tabular}

1.5 Generation

\begin{tabular}{|l|c|c|c|c|c|}
\hline Holly & 19 & F & $\sqrt{ }$ & $\sqrt{ }$ & Hong Kong (NZ) ${ }^{34}$ \\
\hline Arnold & 22 & M & $\sqrt{ }$ & $\sqrt{ }$ & Hong Kong \\
\hline Carol & 22 & F & $\sqrt{ }$ & $\sqrt{ }$ & Hong Kong \\
\hline Sam & 31 & M & $\sqrt{ }$ & $\sqrt{ }$ & Taiwan \\
\hline Kathryn & 30 & F & $\sqrt{ }$ & $\sqrt{ }$ & Taiwan \\
\hline
\end{tabular}

New Zealand-born

\begin{tabular}{|l|c|c|c|c|c|}
\hline Susan & 24 & F & $\sqrt{ }$ & $\sqrt{ }$ & NZ \\
\hline Maggie & 24 & F & $\sqrt{ }$ & $\sqrt{ }$ & NZ \\
\hline Laurie & 23 & F & $\sqrt{ }$ & $\sqrt{ }$ & NZ \\
\hline Adrienne & 24 & F & $\times$ & $\sqrt{ }$ & NZ \\
\hline Sasha & 22 & F & $\times$ & $\sqrt{ }$ & \\
\hline
\end{tabular}

Table 1. Participant Information

$3^{2}$ Was eligible to vote in the 2014 election and was enrolled to vote.

33 Neither Victoria nor Phoebe were eligible to vote in the 2014 election as they had not had New Zealand residency for more than twelve months.

34 Holly was born in New Zealand but returned to Hong Kong with her parents shortly after her birth; they migrated back to New Zealand when Holly was five years old hence why she is categorised as 1.5 generation. 


\begin{tabular}{|l|l|l|}
\hline Length of residence & Ethnicity 35 & Occupation \\
\hline
\end{tabular}

\begin{tabular}{|c|c|l|}
\hline 3 years & Singaporean Chinese & Undergraduate - Humanities \\
\hline 4 years & Chinese & Financial Analyst \\
\hline 5 years & Chinese & Undergraduate - Architecture \\
\hline 7 years & Taiwanese & Mother/Part-time Cleaner \\
\hline 10 years & Chinese & Undergraduate - Commerce \\
\hline
\end{tabular}

\begin{tabular}{|l|c|l|}
\hline 13 years & Chinese & Undergraduate - Commerce \\
\hline 13 years & Hong Kong Chinese & Postgraduate \\
\hline 16 years & Chinese & Postgraduate - Architecture \\
\hline 18 years & Chinese & Market Access Advisor \\
\hline 18 years & Chinese & Mother/Laboratory Scientist 36 \\
\hline
\end{tabular}

\begin{tabular}{|c|c|l|}
\hline- & Singaporean Chinese & Assistant Management Accountant \\
\hline- & New Zealand Chinese & Assistant Analyst \\
\hline- & Malaysian Chinese & Postgraduate - Architecture \\
\hline- & New Zealand Chinese & Postgraduate - Architecture \\
\hline- & New Zealand Chinese & Undergraduate - Criminology \\
\hline
\end{tabular}

35 These ethnicities were self-determined.

${ }^{36}$ Kathryn is currently on maternity leave. 


\section{I. $1^{\text {st }}$ Generation Immigrants}

The following five interviews are outlined in order of period of residence in New Zealand. Victoria and Phoebe had been resident in New Zealand for three and four years respectively. Johnny, Ashleigh and Patrick had been resident in New Zealand for five, seven and fourteen years respectively. Victoria migrated from Singapore; Ashleigh, from Taiwan whilst Phoebe, Johnny and Patrick had migrated from China. Three out of five $1^{\text {st }}$ generation migrant participants voted in the 2014 election. Johnny, Ashleigh and Patrick voted whilst Phoebe and Victoria did not. However, neither Phoebe nor Victoria were eligible to enrol or to vote at the time of the election in September 2014.

Victoria

Victoria, 19, migrated from Singapore in 2012 and did not vote in the 2014 election, though she was ineligible to vote as she does not have a permanent resident visa. Victoria has been resident in New Zealand for three years. Victoria found her last year of secondary school in Singapore too stressful. Her parents had been posted in New Zealand for work so she migrated to New Zealand to study. Victoria did her final year of secondary school at an international college, gained her International Baccalaureate Diploma and has completed her first year of an undergraduate degree in International Relations.

Victoria did not appear to be aware of ineligibility to vote in 2014 because when asked what her main reason for not voting was she replied: "Because I was just too busy to read about the news but like I know that [the] National party lost, or maybe...I can't remember." 37 Victoria's response to my question about her political news sources was: “Actually I'm not very interested in [New Zealand] politics, I don't really keep in touch. So I mainly read international news. I don't really follow any political news here in New Zealand other than like, I don't think I follow any elections, no." Victoria told me she is more interested in international relations than New Zealand politics. Regarding news on these topics she reads The Economist or Foreign Policy.

Victoria also gleans political news and information through her social networks. I asked Victoria about other sources and she responded: “...yeah friends,

37 In reality the National Party won the 2014 election (Freedom House, 2015). 
Facebook, yeah I think last week I think there was a TPPA Walk Away so I have a friend [Shane] who was really interested in that and he was like 'are you interested in that?' and I was like 'not really but I can take a look at what it is' and yeah he told me about TPPA which I wasn't really sure [about] and I didn't really care so he stated that how TPPA is negotiated in secrecy, yeah he's like the main source where I learn all my political news".

Victoria calls her parents every week and she is in contact with her friends daily as she lives in a university hall of residence. She also has friends in Singapore whom she contacts using Whatsapp or Facebook. She also noted difficulty integrating in New Zealand: "my friends here in Wellington they are mainly Asian, yeah I cannot seem to integrate into like New Zealand community because I don't know I find it quite awkward, yeah even though it has been quite long." Victoria thought that her friends and family had voted in the 2014 election, though she did not give any reasons for their decision to vote. Victoria is a member of Amnesty International and has recently joined the 350, a global anti-climate change group.

Phoebe

Phoebe, 27, migrated from China in 2011 and did not vote in the 2014 election. Phoebe was not eligible to enrol to vote as she had only been granted permanent residency in June 2015. Phoebe has been resident in New Zealand for four years. Whilst Phoebe completed her degree in Business Administration in China she wanted to migrate to a "western developed country" to carry out further study and find work. "New Zealand and Australia were the ones I really liked, the environment and then people also speak English, which I had been learning, studying since I was a kid and then the reason is, it's affordable for my parents". Once in New Zealand, Phoebe did a Masters of Professional Accounting and since graduating has been working as an accountant.

Despite not being eligible to vote Phoebe stated "Yeah I wanted to vote, I just couldn't". After asking her to explain her desire to vote, Phoebe replied: "I have never voted in my whole life and I think one of the benefits of being in a democratic country is that you are part of what's happening in the country and what you are saying and what you are doing would impact on [where] the 
country is going maybe the impact is teeny tiny but I would like to do it because you know in China it doesn't matter, as long as you are not [in] the government, it doesn't matter what you think or what you do." Phoebe gets her news online, on her phone or she reads the newspaper at work, where they get the Dominion Post. Phoebe does not discuss politics with others often although she told me "I used to live with a Kiwi lady when I was a student. She [was] very interested in politics so we talked about New Zealand politics a lot, almost every day when we watched the news. But when I started my job I moved out so I don't have a lot of time to watch news with someone else so I don't talk about politics with people a lot."

Phoebe contacts her family, mainly her Dad, weekly or fortnightly by phone and her contact with her friends ranges from daily to weekly. She contacts her friends in Wellington mainly by text and sees them in person as she does not use Facebook or other social media often. Regarding contact with friends in China she had mostly lost contact with them; the last time she had been back to visit family was in 2014. Phoebe is a member of the Public Service Association and the Chartered Accountants Australia and New Zealand.

\section{Johnny}

Johnny, 25, migrated from China in 2010 and voted in the 2014 election. Johnny has been resident in New Zealand for five years. Johnny migrated to New Zealand for his tertiary education. He completed his final year of secondary school in New Zealand and carried out a degree in Computer Science. He worked for a year but "didn't feel that much passion", after which he chose to return to university to study Architecture. He has just completed his second year of a degree in Architecture.

Johnny stated that "getting to vote is really important as a member of the society..." Johnny highlighted that becoming a permanent resident mobilised him to inform himself: “during my first few years in New Zealand I didn't care I thought 'Oh why should I care? I've never cared'. But right after I got residency I thought ok I'm a member [of] society now I should make sure I'm aware of what's happening so then I had a look at what was going on and why it's going on so I'm more aware of politics now than before definitely." A proactive 
individual, Johnny sought information regarding political parties and their policies in an attempt to educate himself about New Zealand's political system.

Johnny also gleans information on Chinese political issues from his father, and New Zealand political issues from friends, indicating the significance of peer group and family for Johnny's political socialisation. When I asked where Johnny gets his political news he replied: "mainly [the] internet and my father is really interested in politics so he talks to me about politics all the time...Because I voted last year and I was discussing the whole voting process with my flatmate in the hall of residence so because like that's my first time voting both in China and New Zealand so it's really a new experience for me. Actually during that time I talked a lot about politics, I was doing it by myself."

Johnny messages and sees his friends in New Zealand daily and often talks to his Dad on the phone. He had actually spoken with his father the night before the interview: "he was talking to me about some people in high level was pulled down because of corruption because like China is now really focusing on their anti-corruption campaign, something like that..." Johnny also travels back to China every summer break to visit his family and for Chinese New Year. Johnny is not a regular member of any groups though he had joined Toastmasters and UniQ, a representative group for queer students, for a period of time, but does not currently attend meetings for either. He also attends casual Badminton sessions at the university recreation centre.

\section{Ashleigh}

Ashleigh, 35, migrated from Taiwan in 2008 and voted in the 2014 election. Ashleigh has been resident in New Zealand for seven years. She met her New Zealand-born husband Robert in Taiwan when he was an English teacher in Taiwan. He wanted to return to New Zealand to study Law so Ashleigh came to New Zealand with him. They now have a four year old daughter and Ashleigh is occupied part time as a cleaner.

In the past election Ashleigh was encouraged to cast her vote on Election Day by her husband, "[Robert] was just like 'go for it' and sometimes I just thought oh I can't be bothered and Robert would just push me..." Ashleigh told of often bringing newspapers home to her flatmate Paul, to discuss interesting articles. 
Ashleigh also sought to inform herself with help from others regarding New Zealand and global political news: "All my political knowledge is through my friend [Paul] and my husband, and because [in] my household, we don't have TV, we don't have newspaper[s] but my husband he's really into the stuff we're talking about."

Ashleigh exhibited in-depth knowledge of recent Taiwanese political history which is partly due to her interest in Taiwanese politics and the connections she maintains with her Taiwanese family and friends who keep her informed about current political affairs in Taiwan such as elections. When I asked Ashleigh about the last time she had a political conversation with someone she recounted a conversation she had had with a cousin regarding the results of the 2012 Taiwanese national election. Ashleigh said she instigated the conversation with her cousin and went on to give me details of different arguments people used for and against the current President's focus on the economy and his stance on China-Taiwan relations. She also gave me a more recent example of a political conversation she had had with her flatmate, earlier that day regarding the Chinese stock market as well as the Auckland housing crisis.

Ashleigh checks Facebook every day to keep up to date with all her friends and family from Taiwan. She also uses Skype and Facebook video to contact them. Ashleigh's husband Robert and flatmate Paul, with whom she spends a lot of time, both voted in the 2014 election. Ashleigh is a member of Greenpeace but told me of no other group membership.

\section{Patrick}

Patrick, 34, migrated from China in 2001 and voted in the 2014 election. Patrick has been resident in New Zealand for fourteen years. He had finished secondary school when he migrated to New Zealand. Once in New Zealand he completed a degree in accounting. After this he worked as a chef for ten years before returning to study. He has just completed his first year of a degree in Finance, after which he plans to find work in finance and accounting.

I asked Patrick what motivated him to vote in 2014. He replied: "I just wanted to give my voice...like I'm coming from China and because of the background I grew up [in] it's different from people from here. There are lots of groups of 
Chinese living here and we probably share the same background and I want to give that kind of voice to the government..." Patrick gets his political news "from Stuff38, sometimes I read Stuff, or me and my friends we talk about it and we don't really want to get too deep into it and different people have different like opinions about parties". The last conversation Patrick had had about a political issue was the previous week and was with his friend's mother, Judy. They had been discussing the explosion in Tianjin, in China, and she told Patrick of a conspiracy theory about the real cause of the explosion, suggesting that it may have had something to do with China-United States relations. 39

Patrick sees his friends at least once or twice a week but has mostly lost contact with friends in China. He speaks with his family back in Shanghai at least a few times a week via Skype and tries to go back for visits every year around Chinese New Year. Patrick sees himself remaining in New Zealand for the foreseeable future but attributes his desire not to apply for New Zealand citizenship to frequent trips to China. Patrick would have to forfeit his Chinese citizenship ${ }^{40}$ for New Zealand citizenship which would make travelling back to China more difficult as he would have to apply for a visa each time. Patrick thought his friends voted in the 2014 election. He told me he thought their motivations were "they wanted to be heard as well". Patrick is also a member of a "national poker club" which meets at a pub weekly.

\section{1.5 Generation Immigrants}

Carol, originally from Hong Kong, has been in New Zealand for seven years; Arnold and Holly, a brother and sister, migrated from Hong Kong thirteen years ago; Sam and Kathryn, a husband and wife, have been in New Zealand for eighteen years after migrating separately with their families. All five 1.5 generation migrant participants voted in the 2014 election.

\footnotetext{
${ }^{8}$ Stuff is a New Zealand news website.

39 Firstly, Patrick refers to numerous explosions, in Tianjin, at a port warehouse containing both hazardous and flammable chemicals which occurred in August, 2015 (BBC News, 2015). Secondly, the conspiracy Patrick alluded to was based upon a connection made between the Tianjin explosions and China's currency devaluation, also in August 2015, which was condemned by United States lawmakers and the United States Treasury (Sweeny \& Lu, 2015).

40 As of September 10, 1980 Article Three of the Nationality Law of the People's Republic of China declares "The People's Republic of China does not recognise dual nationality for any Chinese national" (Nationality Law of the People's Republic of China, 1980).
} 


\section{Holly}

Holly, 19, migrated from Hong Kong in 2002 and voted in the 2014 election. Holly has been resident in New Zealand for thirteen years. Holly and her family migrated to New Zealand from Hong Kong in 2002 when she was five years old. Her parents had travelled to New Zealand prior to this; in fact Holly was born in New Zealand though they returned to Hong Kong after and remained there until 2002. Holly had two other brothers, one older (Arnold who I will discuss next) and one younger, both of whom were born in Hong Kong. She has just finished her second year of an Accounting and Finance degree.

Holly did not cite a particular reason for voting other than it was her first time voting and that her entire family walked down to the polling station together on Election Day. For Holly it was a new experience, perhaps even a rite of passage. Holly was encouraged by her family to vote in the past election and did so despite not receiving encouragement among her peer groups, who did not vote in the 2014 election. Holly's political news sources are Stuff.co.nz, Twitter and Facebook. However, there was one particular issue that was brought to her attention by her brother, Arnold. Arnold told her about the Hong Kong protests and told her to go online where she could watch the live stream; her grandfather in Hong Kong also kept her informed regarding this particular event. Holly does not discuss political issues with her friends, aside from the topical flag referendum, which she had discussed two to three weeks ago.

Regarding contact with friends and family Holly said: "Every day I guess. Well I live with my parents and stuff so I see them every day. And my friends usually it's just at Uni I see them around Uni and on weekends sometimes we hang out otherwise like texting and Facebook kind of stuff like social media and talking on that." Holly has travelled back to Hong Kong twice and was going back at the end of 2015. Holly indicated that her friends did not care much about political issues, "most of my friends I heard didn't vote. I'm not sure why but they just didn't. I think that they didn't care who was the Prime Minister or anything. But my whole family who was over 18 voted”. I asked Holly about her family's motivations for voting. She replied: “...well because my parents have a mortgage and they're working people they don't have their own business so like if they want Labour they have better policies for those types of people 
but I have my Aunty who's got a business and she'd always vote National 'cause it's better for business". Holly is not a member of any groups other than a few study groups through the university which make contact through Facebook.

\section{Arnold}

Arnold, 22, migrated from Hong Kong in 2002 and voted in the 2014 election. Arnold has been resident in New Zealand for thirteen years. His family migrated to New Zealand from Hong Kong. This included his mother, father, Arnold, Holly (Arnold's younger sister) and their younger brother. Arnold has just completed his final year of a Bachelor of Commerce with Honours in finance. Arnold currently works part-time in an investment team and will transition to full-time work in 2016.

When I asked him, Arnold was originally unsure of his motivations for voting in 2014. He had not voted in the first election for which he was eligible, in 2011, and he reflected on his reasons for first not voting and, later, voting:

...I guess the reason I missed my first election was [because it was] my first year of university and I didn't really care about what's going on around the world. Just kind of worry about my own things. But I guess, also after they changed the student allowance criteria, I think if you do post grad, or something, or Masters, you can't get student allowance anymore so that kind of grabbed my attention and was like well like it actually affects me quite a bit because I'm on student allowance right now. ${ }^{41}$

...we kind of went as family because we can vote at the local school and that was only two minutes away and it was like why not, let's go and get that [done]. And friends I guess, most did because leading up to election we did kind of ask 'who are you going to vote [for]?', so we did have some talk about that, and I'm pretty sure they voted as well when it [was] such a big deal in the media, especially talking about trying to encourage young people to vote. So I guess that kind of got

${ }^{41}$ The changes to which Arnold refers were made in 2013 to student allowances which meant the student allowance was no longer available for postgraduate study except for those studying a Bachelors with Honours. 
to us and we thought oh maybe we should vote even though we might think our vote doesn't really make a big difference I guess but we just vote anyway just for the sake of it sort of, make everyone happy I guess.

With this response Arnold summed up: his shift from non-voter in 2011 to voter in 2014; that he was encouraged by his family to vote; that he had discussed the election with his friends; and considered his own participation in relation to campaigns aimed at increasing participation during the 2014 election. ${ }^{42}$

Arnold sees his friends from university every day, other friends on a weekly basis, and lives at home with his parents. However, since his parents both work six days a week at a bakery they are often at work by the time he wakes up and by the time he comes back home in the evening they are often asleep. As indicated by Arnold above: his family voted and he thinks his friends voted as well. Arnold also keeps in contact with a primary school friend from Hong Kong and has been back once to see family there.

\section{Carol}

Carol, 22, migrated from Japan in 1999 and voted in the 2014 election. Carol has been resident in New Zealand for sixteen years. Originally from Hong Kong, Carol and her parents migrated to Japan when she was four months old. When Carol was six years old they migrated to New Zealand. Carol carried out most of her primary and secondary schooling in New Zealand apart from one year of primary school in Singapore and one year of secondary school in Britain. Overall she has spent just over half of her school years in New Zealand, and has just completed the first part of a two year Masters course in Architecture. Carol spent most of her first six years in Japan, though her family maintain connections with family in Hong Kong as her grandparents live there.

Carol gave me her reasons for voting: "I think because we're lucky enough to have the vote and everything so I think everyone should vote and make their voice count. Yeah even though you may not think one vote makes a difference,

\footnotetext{
$4^{2}$ Arnold refers to campaigns such as the Electoral Commission's campaign dubbed 'Your Vote is a Powerful Thing' amidst discussion of low voter turnout among youth, as a week prior to the election approximately one quarter of eligible voters under $30-200,000-$ had not enrolled (Electoral Commission, 2014; Radio New Zealand, 2014).
} 
you know it kind of does when it all adds up and there are some things that, you know parties that don't currently have these seats or whatever to enforce their policies, it's good to support them in the vote." The most recent conversation Carol had had about a political issue was the day prior to the interview, which had been with a group of friends. This particular conversation was regarding the referenda to change the New Zealand flag, the first of which was held in November 2015.

Carol is in contact with her family every other day and contacts her friends every day. Carol also has many friends overseas including Australia, Switzerland, Sweden, Scotland and England. She contacts them online frequently and has been writing letters to her friend in Sydney for thirteen years. Although she migrated at four months old, Carol also maintains contact with her family in Hong Kong. She travels to Hong Kong every one or two years (she was there earlier in 2015) and calls her grandparents with whom she speaks Cantonese. Carol told me her friends and family also voted and thought their reasons would be similar to her reasons regarding the responsibilities accompanying the privilege of suffrage. Carol is also a member of two architecture organisations: Architecture + Women and the Student Architecture Network New Zealand. The latter involves events and meetings: “...we have date nights where we, the students get to meet working female architects and network and stuff and there's been some exhibits put on and that sort of thing..."

\section{Sam}

Sam, 31, migrated from Taiwan in 1997 and voted in the 2014 election. He has been resident in New Zealand for eighteen years. Sam migrated to New Zealand from Taiwan with his family when he was 13 years old. His parents chose to migrate, Sam said, due to stability, education and the environment in general. He said it may have been the result of perceived instability due to tensions between Taiwan and China. Sam did his PhD in Microbiology, is now working as an advisor for a market access team in a government Ministry and has a young son with his wife Kathryn, who I discuss next. 
Sam told me that he had voted because he wanted a change of government, but he felt there were not any viable alternatives to the incumbent; overall he felt that people could not really make a difference to political decision-making. When I asked Sam where he gets his political news he replied: “...actually because some of my friends are quite active, not politically, some of them are politically active or have very strong views, I quite often get them on Facebook or get headlines, I must say I'm not, I don't particularly trust our media, yeah so I think the first source would be social media”.

Regarding political issues, Sam told me "I talk to my wife quite often about these issues." He said it was probably a couple of days previous and they had discussed a number of issues such as the TPPA, the housing issue and about the flag referendum, specifically that Sam thought it was "a decoy for real issues". However, Sam also told me that he felt that to an extent he should not discuss political issues: “ [I] wonder whether because we are in [the] public service some parts of our rights have been taken away in a way that we're trying to avoid being, we're trying to be impartial in our jobs, which we do, but I almost feel like you cannot have your view outside of your job, like if I were just a citizen I would go, I could probably feel more, be more willing to say, request an OI [official information], rather than, compared to now where I'm in in the public service, I don't feel like I have the, I almost feel like I don't have the right to, or I might get into trouble if I do.”

Sam was not specific about how often he contacts friends and family but did say that he checks Facebook at least once a day to see what his connections are doing. Sam also keeps in touch with his sisters and stepmother back in Taiwan. His stepmother had just recently visited him and Kathryn, though Sam does not travel back often. Sam had been part of the Asia New Zealand leadership network; the Chinese Friendship Society; and the New Zealand China Trade Association; was involved with the American Society for Microbiology and is an active part of the Asia Forum. 43

\section{Kathryn}

43 The Asia is a discussion group which meets monthly; their central objective is improved interdisciplinary understanding of Asian politics and its implications for trade and investment (“Asia Forum,” 2016). 
Kathryn, 30, migrated from Taiwan in 1997 and she voted in the 2014 election. She has been resident in New Zealand for eighteen years. Kathryn and her family migrated from Taiwan when she was 12 years old. Her father was in the Taiwanese air force. Kathryn explained "I think lots of his friends decided to migrate to New Zealand back in $1995^{44}$. So then he came here and thought 'Oh New Zealand is great, it's a great place to raise children' so he decided to move here”. Upon arrival she started school in year eight45. Kathryn told me she found settling in a struggle to begin with: “... Because of the language.... Back in Taiwan we learned English but it was only simple greeting English, like what my name was and how are you doing, things like that. So I would go home and cry for the first three months." Kathryn completed a degree in Biomedical Science and post-graduate study in medical laboratory science. She now works in a hospital laboratory as a laboratory scientist. She and Sam have a young son and Kathryn was on maternity leave at the time of the interview though she returned to work in January 2016.

Kathryn said she did not 100 per cent agree with the current government but the party she wanted to vote for did not have a strong leader. She was unsure who she should vote for but felt compelled to vote regardless, she stated "[I was] trying to express my view, but I don't think it made much difference, but if I didn't vote I'd be gutted, so yeah, I always vote, just to express my feeling”. Kathryn gleans her political news from news websites, the television and radio and, occasionally, social media. She discusses political issues with her husband and cited a conversation she had had with her friend a few days earlier regarding the introduction of GST to online shopping. ${ }^{46}$

Kathryn contacts her friends and family almost every day via phone calls, Facebook or Skype. She thought most of her friends and family would have voted as well and had the same motivations as she did, wanting to express her views and feelings. Kathryn's parents returned to Taiwan eight years ago though her mother tries to visit each year and visited them last in 2014. During secondary school and university summer breaks, Kathryn

44 After 1987 Taiwanese migration to New Zealand increased, reaching its peak of 12,000 residential approvals in 1995. (Asia New Zealand, n.d.)

45 Aged 12 years.

${ }^{46}$ Kathryn and her friend were discussing the Government's proposal and plans to apply GST to goods and services bought online or from overseas (Bramwell, 2015). 
would travel back to Taiwan and visit family though does not any more since she started work. Her last trip was three or four years back now, though she maintains contact via email, social media and calls her grandparents by phone. Kathryn is a member of a group from Parent Centres New Zealand Inc. This is a group of other women with whom Kathryn attended antenatal classes; they still maintain contact and catch up on a weekly basis.

\section{New Zealand-born}

Three out of five New Zealand-born participants voted in the 2014 election. Susan, Maggie and Laurie voted whilst Adrienne and Sasha did not.

\section{Susan}

Susan, 24, voted in the 2014 election. Her mother is also New Zealand-born whilst her father is a $1^{\text {st }}$ generation immigrant from Singapore. Susan's father migrated when he was around 20 years old to go to university in New Zealand. Susan's maternal grandparents migrated here from Hong Kong, she guessed, "in want of a better life". When they first moved, Susan's grandfather worked in a factory whilst her grandmother stayed at home. Later on they ran a fruit shop which formed most of their income. Susan completed a Bachelor of Commerce and has worked as an accounts administrator and assistant management accountant for one year and a half.

When I asked about her motivations for voting she responded: "I guess to have your say, I guess about how you want your country to be run or to, what path they should go down. But I think everyone should have a vote because otherwise if you complain afterwards [about] what happens it's only yourself to blame if you don't have your say." Susan gets her political news from the newspaper, television and from Stuff.co.nz. In relation to the 2014 election her information was from listening to the views of others and her family in addition to her regular news sources. The last conversation Susan had about a political issue was in the week prior to the interview and was regarding the housing crisis, specifically in Auckland, and the perception that foreign investors are buying up New Zealand property and driving house prices up. 
Susan lives with her parents; has contact with some friends every day and whenever she can get a spare moment with others. She either sees these friends or contacts them by text or Facebook messenger. Susan thought the majority of her friends and family voted and that their reasons for voting were similar to her own, that it is important for people to have a say about how they want their country to be run and contribute to the political decision-making process. Susan and her family maintain contact with her father's family in Singapore and travel to Singapore almost annually. Susan is a member of Chartered Accountants Australia and New Zealand; and she belongs to online groups for buying and selling clothing.

\section{Maggie}

Maggie, 24, voted in the 2014 election. Maggie's mother is New Zealand-born and her father is a $1^{\text {st }}$ generation migrant from Malaysia. He was born in Malaysia, studied in Britain and migrated to New Zealand where he met Maggie's mother. Maggie's maternal grandmother was a political refugee from China and her grandfather was a missionary who, along with his father, started the Wellington Chinese Baptist Church. The two met and opened a fruit shop together on Lambton Quay where Maggie's mother and aunts and uncles worked in their youth. Maggie carried out a degree in Law and Commerce, majoring in Economics. She now works as an assistant analyst.

Maggie responded in the following way to my question regarding her reasons for voting: "I think a lot of it's just to do with like we have the right and it's not even just the right it's kind of like a privilege to be able to vote and I feel like if you're going to complain about things you can't if you haven't voted and tried to inform yourself on what's happening and what you think can affect the decisions and the results. I get really sick of people who moan about things who don't try to change anything so it's just like that's one little thing you can do. If I'm not informed consistently at least up to election I will try and be as informed as possible so that I can make a good decision for myself. And it's just like not every country is democratic and not every country, it's not been very long that females have had the right to vote even so it's just like one little thing that you can do". When I asked Maggie where she gets her political news from she responded "probably to be honest, other people that I know. So it's 
probably more like my peer group but then again I'm not super involved in politics myself either so I guess it's just the general: internet [and] social media. [On politics] It's not really something I talk a lot about with my family or my parents.”

Maggie said her contact with family and friends really depends on who it is but overall "almost a daily basis or at least weekly, fairly regularly. I'm in contact with my parents quite regularly". If not in person then Maggie would usually use Facebook, text and, occasionally, Skype. Maggie said she has friends "who are super active and have party membership" so she would say most of them voted in the 2014 election and could not think of anyone who had not voted. Maggie is a member of a social netball team at her work and is also part of the committee which organises the work Christmas Party. She also attends events held by the Young Lawyers Committee of the New Zealand Law Society as many of her friends are lawyers and also attend these events.

\section{Laurie}

Laurie, 23, voted in the 2014 election. Laurie's parents migrated to New Zealand thirty years ago with her older brother and sister from Johabaru, Malaysia:

“...they moved here just because they needed a new life pretty much, they wanted to start over. And they came here, they shared a house with five other families in Newtown, they shared a bedroom, like my whole family they shared a bedroom. And they pretty much went from zero to owning businesses, yeah it's like really inspiring...my mum used to work from home sewing shoes and my dad started off as a dishy in a random restaurant and he ended up owning his [own] restaurants and becoming head chef".

Laurie has finished her Bachelor of Architecture and a Post-Graduate Diploma with the plan to join the Master's programme in 2016 at the architecture school.

Laurie's reason for voting was: "I mean if we want to change something then that's our chance. And you see people who sit there and complain but they don't vote and it's like, come on that's your chance”. Laurie's 
response to my question on her political news sources was: "I don't really...no. Just the internet, yeah like websites, social media or Stuff". Laurie's hesitation was regarding her news sources. She first thought she did not really read or hear any political news but she then identified the sources above. I asked Laurie when the last time she had a conversation about a political issue was, she responded: “I don't even remember, no. I mean the flag? Is something, I talk about that with my friends, maybe last week...but yeah it's not often".

She lives with her parents and sees her boyfriend and university friends daily. Laurie and her family travel back to Malaysia every year. Laurie's older sister migrated back to Malaysia, though they have been making trips to Malaysia since Laurie was young. Her friends voted as well and her family, too, as they go to the polling station together. Laurie thought her friends' and family's motivations would mirror hers. Although Laurie told me she would like to do her own research prior to next election "because the last time I voted I talked to my parents about [it] and they sort of gave, I don't know, because I don't know who to pick normally. I just go for whoever my parents go for, yeah". Laurie is part of several study groups, operating partly online via Facebook. Laurie sees her friends and family every day.

\section{Adrienne}

Adrienne, 24, did not vote in the 2014 election. Adrienne's mother is from Hong Kong and her father is from Guangzhou, China. They migrated with their separate families once they had finished school and were in their twenties, Adrienne said, "probably a good thirty years ago", though she was unsure of the exact year. While Adrienne was growing up her parents ran a Fish and Chip shop. She and her siblings would go and help their parents out at the shop after school. Adrienne has completed her Bachelor of Architecture and is currently in her second year of the Master's programme.

In her own words, Adrienne did not vote because: 
“I just wasn't that interested to be honest. I wasn't particularly for any party and I feel like the whole point of voting is you vote because you want this particular party to win or you want this particular person to stay in. Um, but for me I didn't feel like any of them so I thought well if I don't really have an opinion then my vote's not going to be worth anything, it's just going to be I'm voting to do it. I don't have any particular motivation to do it, yeah...I'm just not that interested in politics in general to be honest. I don't feel like I should partake in something like that".

Adrienne thought she may have voted in the previous election in 2011, though she was unsure. She thinks she may have voted for National but then they made changes to student allowances which affected her and her friends: "...it just made it harder on a lot of people, like a lot of my friends, myself included and it was like, man I don't want to vote for anyone". Adrienne's main source of political issues is from television, sometimes radio and news websites such as 3 News, The Herald, and Stuff, "I don't really go outside those platforms 'cause I'm used to checking those all the time". The last political conversation Adrienne had had was a week prior to the interview and was regarding the refugee crisis and whether or not New Zealand should let more people into the country and comparing it to the efforts of other European countries such as Germany and Hungary.

Adrienne contacts her parents, who live in Auckland, by email weekly and sees them two or three times a year. Adrienne lives with her siblings in an apartment their parents bought for them so she sees them regularly. She sees her friends in Wellington every week, and she sees friends living in different cities once a year. She has also made a few international friends during her time at university and keeps in contact with, mainly using social media such as Facebook and also Skype. I asked Adrienne whether her friends and family voted in the 2014 election; she replied: "Yeah, friends yes. Family, probably not. My family is just not that interested in that, yeah". Regarding her friends' motivations Adrienne responded: "I think they're more, their families would have voted as well. Maybe they're better informed than I am, because they might actually look up what each party represents”. Adrienne also attributed 
this to social and political context, she thought that her friends who knew a lot about politics and were interested also studied Commerce but that she and others studying the Arts did not care as much. Regarding group membership, Adrienne is part of a casual running group.

Sasha

Sasha, 22, did not vote in the 2014 election. Both of her parents are New Zealand-born Chinese. Sasha's maternal grandmother migrated from Guangzhou in China at three years of age, though Sasha is unsure of her maternal grandfather's migration to New Zealand. Sasha's paternal grandparents migrated together in their twenties but she is not sure exactly of when or how old they were at the time of migration. Sasha has just completed a degree in Criminology and Sociology.

In her own words, Sasha did not vote because: "I didn't want to have a say. 'Cause everyone in my household was going on and on about it and I was just like, I don't know, I didn't really get into it as much. I didn't look into it as much, I didn't think I knew who I wanted to vote for exactly whereas I just heard everyone else's opinions". Sasha gets her political news from her mother "because she's probably the only one really who is into, or takes an interest in political views rather than my dad". However Sasha will also obtain political news from Stuff or Facebook. The last conversation Sasha had regarding a political issue was: “...maybe a couple of weeks ago, it would have been something on the news that would have sparked up conversation over the dinner table and my partner is quite opinionated as well. And so him and my mum get on really well and like discuss things like that, but it's more me being uneducated about the topic and asking what is going on rather than like me having an opinion myself". Other than that, Sasha does not have many similar conversations with other friends and would only really bring up a topic if she felt strongly about it.

Sasha lives at home with her family so she sees them every day and sees her friends on weekends. She also contacts a few friends on a daily basis via social media, text, and sometimes Skype. Skype is usually for friends who are overseas who Sasha will contact monthly or every couple of months; she and 
some others will conference call and catch up all together. In the 2014 election all of Sasha's family voted whilst many of her friends did not. But Sasha told me they had voted in the election prior, in 2011, "Cause it was our first time we could vote and thought may as well go do it. Rather than the second time, was more like if you don't have an opinion on it, most of us just sort of left it." Sasha is not a member of any groups other than volunteering with her brother's "special needs group". Every Friday night they will see a film or go bowling and Sasha is on the list if they need help; she does this once every two months.

\subsection{Summary}

Among the $1^{\text {st }}$ generation migrant participants, three - Johnny, Ashleigh and Patrick - voted in the 2014 election whilst two did not. The latter two participants, Victoria and Phoebe, however, were ineligible to vote at the time of the election. Of those who voted Johnny and Patrick experienced their premigration socialisation in China and Ashleigh's was in Taiwan. They had each been resident in New Zealand for five, fourteen and seven years respectively. Victoria experienced her pre-migration socialisation in Singapore and has been resident in New Zealand for three years. Phoebe experienced her pre-migration socialisation in China and had also been resident in New Zealand for three years. The conclusions we can draw from Phoebe and Victoria's cases are limited, however, because they were ineligible to vote at the time of the election. All participants had had conversations about political issues between one day and one week prior to the interview and gleaned their political news from a mixture of news websites, television and from their social networks including peer group and family via conversation or social media. On average this group was in contact with their friends and family between daily to weekly. Among all participants, their friends and family had voted in the 2014 election. Regarding group membership each participant was a member of a group which included local clubs, professional organisations and international not-for-profit organisations.

All five 1.5 generation migrant participants had voted in the 2014 election. Arnold and Holly both experienced their pre-migration socialisation in Hong Kong and have been resident in New Zealand for thirteen years. Carol experienced her pre-migration socialisation in Japan and has been resident in 
New Zealand for the past sixteen years. Sam and Kathryn have both been resident in New Zealand for eighteen years and experienced their pre-migration socialisation in Taiwan. The most recent conversations about political issues had by these participants occurred between one day and one month prior to the interviews. These participants gained their political news from a mixture of news websites, social media and friends and were also in contact with their friends and family, on average, either daily or weekly. The friends and family of these participants also voted in the 2014 election. Group membership among the 1.5 generation migrant participants ranged from study groups and antenatal groups to national organisations.

Three New Zealand-born participants voted in the 2014 election whilst two did not. Susan, Maggie and Laurie voted, though Adrienne and Sasha did not. All five had experienced their political socialisation in New Zealand and had been resident in New Zealand all of their lives. The most recent political conversation, among this group, had occurred in the week prior to the interview, with the exception of Sasha's whose most recent conversation was two weeks prior. They all obtained their political news from a combination of news websites, friends and family. All five New Zealand-born participants are in contact with their friends and family somewhere between daily and weekly. Of the three voters, both their friends and family also voted in the 2014 election. In the case of Adrienne, however, her friends did vote, though her family did not. And in Sasha's case, her family voted whilst her friends did not. Among these participants group memberships ranged from casual running, study groups and work social groups to professional organisations. 


\section{Findings and Analysis}

In this chapter I outline and discuss the central findings of this study with reference to prominent theories of migrant political participation investigated in this research. Firstly, I consider the implications of these findings for acculturation and national origin theories in order to answer the central question of this research: how does pre- and post-migration socialisation affect electoral participation among Chinese in New Zealand. I present any correlations, or lack thereof, between length of residence and electoral participation followed by a discussion of the effects of length of residence upon social networks and political interest. Subsequent to this I discuss the relationship between socialisation in a democratic versus non-democratic regime and electoral participation; political interest; and social networks. Secondly, I highlight how social capital theory, namely social networks as well as political interest; demographic factors such as age and life-cycle; and identity theory are useful for explaining the electoral participation among this sample.

The responses from fifteen interviews demonstrate the weakness of both length of residence and socialisation in a democratic versus non-democratic regime for explaining the drivers of, and barriers to, electoral participation among this sample. Instead demographic factors such as age and, specifically, life-cycle were more relevant among this group and identity, including migrant status and ethnic identity, seemed to influence political engagement and participants among older participants at, relatively, later stages of their life-cycle. The findings also reveal a relationship between the participants' social networks and their political interest and its effect on electoral participation that was unanticipated. These findings demonstrated the overall significance of social capital, specifically social networks, for political interest, political engagement and electoral participation. The findings of Berger et al., (2004), Fennema \& Tillie (1999) and D. Jacobs et al., (2004), that social networks served to both encourage and discourage political interest, engagement and participation also applied among this sample of Chinese in New Zealand. Social network and political interest were not, however, determined by length of residence and 
socialisation in a democratic regime versus non-democratic regime as was originally anticipated in Chapter Two.

\subsection{Acculturation: Length of Residence}

Contrary to expectation, among this sample there was no correlation between length of residence and electoral participation. I based my hypothesis upon one facet of acculturation theory, which asserts that as length of residence increases migrants gain the necessary knowledge, skills and confidence to engage and participate politically. The three categories of participants, $1^{\text {st }}$ generation migrant; 1.5 generation migrant; and New Zealand-born, were utilised to explore this explanation. I anticipated that Victoria, Phoebe, Ashleigh, Johnny and Patrick ( $1^{\text {st }}$ generation migrant participants) 47 would vote least and that Susan, Maggie, Laurie, Adrienne and Sasha (New Zealand-born participants) would vote most. I expected Holly, Arnold, Carol, Sam and Kathryn's (1.5 gen) electoral participation to sit somewhere between that of the two other categories because they have been resident in New Zealand for longer than the $1^{\text {st }}$ generation but less than the New Zealand-born participants.

Phoebe and Victoria ( $1^{\text {st }}$ gen) did not vote in 2014, although they were both ineligible to vote at the time of election; thus we cannot draw conclusions regarding length of residence from this result, although their comments offer insight into their political attitudes and intentions regarding participation. Holly, Arnold, Carol, Sam and Kathryn (1.5 gen) all voted in 2014. Even within the 1.5 generation group, length of residence did not affect electoral participation. Holly and Arnold had been in New Zealand for fourteen years; Carol for sixteen years and Sam and Kathryn for eighteen years, and they all voted. Susan, Maggie and Laurie (NZ-born) all voted whilst Adrienne and Sasha (NZ-born) did not vote. All eligible $1^{\text {st }}$ and 1.5 generation migrant participants voted and despite all being eligible to vote two New Zealand-born participants did not turn out to vote, though the other three did.

Among this sample political interest and social networks were not significantly affected by length of residence. Due to the difficulties of the migration process, including: settling into a new environment; overcoming cultural differences and

${ }^{47}$ Hereafter ( $1^{\text {st }}$ gen$),(1.5$ gen$)$ or (NZ-born) 
barriers; making new friends; maintaining friends and contact in their nation of origin, I expected $1^{\text {st }}$ generation migrants to demonstrate lower levels of political interest and have fewer social networks to facilitate political engagement because they would have had less time to develop these networks and to cultivate their political interest into the New Zealand context. In terms of political interest, the main difference between the three different groups was regarding the most recent conversation participants had had about a political issue. Among the New Zealand-born and 1.5 generation migrant participants this was, on average, a week prior to the interviews. However, for the $1^{\text {st }}$ generation participants it had been slightly more recently, between one day and one week prior to the interview, suggesting that political issues feature more in their conversations compared with those of the other two participant groups. I will discuss the variations in political interest between each of the participants in more depth in section 4.3.

All participants, regardless of their length of residence, were in contact with friends and family between a daily and weekly basis and were members of groups ranging from casual sports and study groups to professional and international organisations. In Johnny's case, in addition to forming and developing many social networks in New Zealand within his five year postmigration socialisation period he remained in regular contact with his father who was a frequent source of political information and would often bring up political issues in their weekly phone calls. This indicates the need to take transnational social networks, and social networks maintained in a migrant's nation of origin into account, as I will discuss further in section 4.3 .

Overall these findings correspond with those of Buck, who found no correlation between length of residence and political participation (2009, p. 67) and Henderson (2013), who found no correlation between length of residence and electoral enrolment. This contradicts Park's (2006) finding that a positive relationship exists between acculturation and voter turnout as based upon length of residence as the measure for acculturation. My research suggests length of residence is not the best, nor should it be the only, measure of acculturation. Excluding Victoria and Phoebe, among this sample, there was no difference between the electoral participation of $1^{\text {st }}$ generation and 1.5 
generation migrants. In order to gain a deeper understanding of the effects of post-migration socialisation on political participation of Chinese in New Zealand, measures of the nature of acculturation, such as civic engagement and integration, rather than just the length of the acculturation process, should be explored further.

If we include the New Zealand-born participants Adrienne and Sasha and compare their non-participation and lack of political interest with Holly and Arnold's (1.5 gen) degree of political interest and that of Sam (1.5 gen), Patrick and Phoebe (1 $1^{\text {st }}$ gen), demographic factors such as age and life-cycle appear to be significant. Neither Adrienne nor Sasha, New Zealand-born, voted in the 2014 election. Adrienne expressed that she was not interested in politics and Sasha had conveyed that she did not want to have a say. Holly and Arnold did vote but Holly expressed that she lacked political interest and her most recent political conversation had been two to three weeks prior to the interview. Arnold was comparably more interested but had only developed his political interest in 2013, evidenced by his heightened interest and awareness subsequent to changes made to criteria for student allowance eligibility in 2013. Sam, Patrick and Phoebe all demonstrated comparably more interest compared with these four younger participants. However, I will further discuss the application of demographic theory for the electoral participation of this group in section 4.3.

4.2 National Origin: Socialisation in a democratic versus non-democratic regime

In the case of this sample, there was a similarly weak correlation between socialisation in a democratic regime versus non-democratic regime and electoral participation. The findings from this sample aligned with recent international literature that has found no significant effects of socialisation in an authoritarian regime on electoral participation (Bilodeau, 2008; Bilodeau et al., 2010). This contrasted with other research which has found a correlation between national origin and electoral enrolment and, specifically, between socialisation in an authoritarian regime and low voter turnout (Bueker, 2005; Henderson, 2013, p. 17; Ramakrishnan, 2005). For this reason I wanted to examine the effect of pre-migration socialisation on electoral participation 
among a sample of young ethnically Chinese individuals who had each received their socialisation in countries of varying regime classification. Pre-migration socialisation in a non-democratic regime such as China did not negatively affect electoral participation. For example, Johnny and Patrick had both migrated from China and voted in the 2014 election. Johnny's motivation was a desire to contribute to society once he gained his New Zealand residency and identified as a part of the community. Patrick's incentive to vote was to represent other Chinese migrants to New Zealand, whom he believed shared similar background and experiences with him. Patrick's identification with other Chinese migrants was of interest, as I will discuss in section 4.3.

Regarding the non-participation of Adrienne and Sasha, both New Zealandborn, socialisation in a democratic regime did not positively affect electoral participation. Contrary to expectation based upon national origin theory, Adrienne and Sasha did not vote in the 2014 election. Adrienne attributed her decision to a lack of interest and Sasha attributed hers to a lack of strong views regarding which political parties and elites should be elected. Both Maggie and Laurie (New Zealand-born participants) voted in 2014 but expressed a lack of political interest. Maggie identified that she was not "super involved in politics" and Laurie could not remember the last political conversation she had had, other than regarding the New Zealand flag referendum approximately one week prior to the interview. Susan had voted in the 2014 election and was motivated by the desire to express her views regarding New Zealand's political decisionmaking by supporting the party and political elites she aligned with.

The responses of these participants indicated no correlation between socialisation in democratic versus non-democratic regime and the degree of political interest or social networks that resulted. This is a finding corroborated by Bilodeau et al. (2010), who found, specifically, that socialisation in an authoritarian regime did not negatively affect voter turnout. All participants, regardless of socialisation in a democratic or non-democratic regime had had conversations about political issues with their friends or family, on average, one week prior to the interview. Among $1^{\text {st }}$ generation participants Johnny and Patrick migrated from China and Victoria, from Singapore, which are both classified as non-democratic and Ashleigh had migrated from Taiwan 
(democratic). On average, these five participants had had a conversation about a political issue more recently than their 1.5 generation and New Zealand-born counterparts. Johnny had had a conversation about corruption in the CCP with his father the night prior to the interview and Ashleigh had discussed a political issue with her flatmate the same day of the interview regarding the Chinese stock market and the housing crisis in New Zealand.

In Johnny and Ashleigh's case it appears the regime type in which they experienced their pre-migration socialisation did not affect their political interest in the way I had originally expected. I expected Ashleigh, having being socialised in a democratic regime, would be more likely to discuss political issues, expressing political interest and be more likely to turnout than Johnny who experienced his socialisation in a non-democratic regime. However, both had had equally recent conversations about political issues, expressed political interest and turned out to vote in the 2014 election. While it is possible that such recent conversations could have been the result of their knowledge that they would be meeting me to discuss political participation, they both indicated other, more recent and frequent, instances of discussion of political issues within their social networks.

The experiences and responses among the 1.5 generation also demonstrated the weak correlation between socialisation in democratic versus non-democratic regime for electoral participation among this sample. The 1.5 generation migrant participants had originally migrated from a range of countries, some classified as democratic and others classified as non-democratic. As aforementioned all five had voted and demonstrated varying degrees of political interest. Holly and Arnold had migrated in 2002 from Hong Kong, classified as non-democratic but with a much more vocal and active civil society compared with other non-democratic regimes such as China and Singapore. Sam and Kathryn had migrated from Taiwan (democratic) and correspondingly expressed political interest, although Sam appeared more interested in politics based on the range of topics he had discussed. Carol experienced her premigration socialisation in Japan (democratic); she and her parents migrated there from Hong Kong approximately four months after Carol was born. However, Carol's responses indicate an ongoing and frequent relationship 
between her family and Hong Kong. She speaks Cantonese fluently, which she uses with her grandparents when she calls them, and she travels to Hong Kong every one to two years, with her last trip there in early 2015.

Holly's most recent political conversation had been with her friends two or three weeks (she was not sure exactly) prior to the interview; apart from this conversation she does not discuss political issues with her friends. Arnold's responses demonstrated an increase in his political interest between the 2011 and 2014 elections. Sam's most recent political conversation had occurred a couple of days prior to the interview and had been about a range of issues including the TPPA, the New Zealand flag referendum, and the housing crisis. Kathryn had had a political conversation with her friend a few days prior to the interview about the proposal to add GST to goods and services purchased online. Carol's most recent conversation about a political issue had been regarding the New Zealand flag referendum the day previous to the interview which had been with a group of friends.

As discussed earlier in this section, the three New Zealand-born participants, Susan, Maggie and Laurie voted in 2014 as expected, based on the relationship found in the literature between socialisation in a democratic versus nondemocratic regime and electoral participation. However, Adrienne and Sasha, the other two New Zealand-born participants, did not vote in 2014 which they both attributed to a lack of political interest. Adrienne's reason for not voting was explicitly, "I just wasn't that interested" whilst part of Sasha's motivation was, “I don't know, I didn't really get into it as much”. Sasha's thoughts on why her and her friends voted in the 2011 election highlighted an initial value of their political rights: "Yeah, I think it's just 'cause it was our first time, we could vote". Sasha attributed her friends' lack of participation in the 2014 election to a lack of opinion “or they just couldn't be bothered”.

One explanation for this could be that once Sasha and her friends, for example, transitioned from secondary school to University and to work, either part-time or full-time they became more concerned with forging their adult lives than developing their political interest, until they form greater social and economic stakes in society and recognise the impact the government's political decisionmaking has for their lives (Buck, 2009, p. 86). This was the case for Arnold 
who did not vote in 2011 because he "didn't really care about what's going around the world. Just kind of worry about my own things" but then voted in 2014 after changes were made to student allowance criteria 2013 and he realised "it actually affects me quite a bit". This could be linked to findings establishing a positive relationship between age and political participation (Buck, 2009; Lien, 1994; Maxwell, 2010). However, age is not specific to the migration experience and this explanation could be applied to many groups within New Zealand.

Another potential explanation, more specific to the migration experience, is that pre-migration socialisation in a non-democratic regime can increase political interest, engagement and political participation. Previous research has found that socialisation in non-democratic regime resulted in higher levels of political efficacy and trust in the regime, which in turn have a positive relationship with political participation (Abramson \& Aldrich, 1982; McAllister \& Makkai, 1992). This would explain the greater political interest and participation among, namely, Johnny, Patrick and Phoebe (all migrants from China). Their political interest and desire to participate politically was much greater by comparison with that of Ashleigh (Taiwanese migrant) and the political interest, engagement and participation of Adrienne and Sasha, both New Zealand-born. Those who have not previously experienced the political rights, such as suffrage, granted within a democratic regime were stimulated by the prospect of having the opportunity to participate and were more likely to appreciate such an opportunity as a privilege. In addition to Johnny and Patrick's desire to contribute to New Zealand society and to represent other Chinese migrants respectively, Phoebe also demonstrated a strong desire to participate despite being ineligible: "I've never voted in my whole life and I think one of the benefits of being in a democratic country is that you are part of what's happening in the country".

Ashleigh, Sam and Kathryn all experienced their pre-migration socialisation in Taiwan and did not demonstrate the same amount of stimulation and optimism regarding their contribution to the political decision-making process and to wider society. Ashleigh expressed that she could not be bothered voting in the 2014 election but was encouraged to by her husband. Neither Sam nor Kathryn 
felt particularly optimistic about their vote in the 2014 but voted anyway. Sam expressed that his motivation for voting in 2014 "was to try and get a change of government but I did feel there was no real option". Kathryn said she was "trying to express [her] views, but I don't think it made much difference". Among this sample the regime in which participants experienced their socialisation did not affect electoral participation in the way I had anticipated.

Contrary to expectations, those participants who appeared the least interested in political issues or stimulated by political participation were New Zealandborn participants, Adrienne and Sasha, or $1^{\text {st }}$ and 1.5 generation migrants who had experienced their political socialisation in a democratic regime, in this case Ashleigh, Sam and Kathryn. Michelson's (2003) finding that acculturation can produce disillusionment with the political regime and ultimately discourage political participation can partly explain these results. This does not necessarily explain the non-participation of Adrienne and Sasha because acculturation does not apply to non-migrants; however Michelson's (2003) emphasis on the role of social networks in this process of socialisation, more broadly, helps to explain the electoral participation of Johnny and Patrick, from a non-democratic background, and, the electoral non-participation of Adrienne and Sasha, from a democratic background. It also helps to explain the disparities between the strong desires of Johnny and Patrick to contribute to the New Zealand community and Sam and Kathryn's feelings that they should vote combined with their doubt about the significance of their contribution.

In these cases, socialisation in a democratic versus non-democratic regime may not be the best measure of national origin and its effect on electoral participation. Socialisation in a democratic regime did not necessarily result in electoral participation and socialisation in a non-democratic regime did not result in non-participation as suggested by Bueker (2005) and Ramakrishnan (2005). Rather, the findings aligned with those of Bilodeau et al. (2010), who found that migrants' electoral activities were not influenced by their premigration socialisation in a non-democratic regime.

4.3 Political Interest and Social Networks: A Relationship of Mutual Influence 
Political interest emerged as significant within these fifteen interviews but not in the way I had anticipated based on the existing literature. Rather than being a direct product of increased length of residence or socialisation in a democratic versus non-democratic regime, political interests, that is, an interest in political issues, appeared to have a much closer relationship with the social networks these participants formed and developed. Overall the relationship proved to be mutually influencing; political interest was both a product of social networks as well as a facilitator of the formation and development of these social networks. Victoria's experience with her friend, Shane, who informed her about the TPPA in general and the 'TPPA Walkaway' march which occurred mid-2015 provides one example of this relationship. This demonstrated social networks encouraging political interest and providing political knowledge.

One basis for the formation of social networks is shared interests, background and experiences. Victoria's friendship with Shane may have developed out of their shared experiences as students and existing political interest. People indicating political interest are, thus, more likely to develop social networks which reinforce political interest. Victoria's response indicates that she and Shane were part of a social network with high levels of political interest. One basis of their friendship may even have been a shared interest in political issues and it was through this initial connection that Shane informed Victoria about a political issue affecting New Zealand. The mutually influencing nature of political interest and social networks, specifically that political interest can encourage the formation of social networks, was not a mechanism that I had considered on the outset of this research.

Arnold's case, however, demonstrated the formation of political interest where previously there was none. Arnold said he was not particularly interested in politics and that he did not vote in the 2011 election as he had just started university and was mostly concerned, and occupied, with that. Arnold attributed his shift in attitude to the change in student allowance criteria in 2013, "so that kind of grabbed my attention". During 2014, leading up to the election in September, Arnold had noticed more politically themed posts on his Facebook newsfeed and had begun to discuss the upcoming election with his friends. 
The explanation offered by Berger et al. (2004), Fennema \& Tillie (1999) and D. Jacobs et al. (2004) that social networks, ethnic communities and ethnic identification were significant influences on political participation assists in understanding electoral participation among this sample. Their research found the social capital hypothesis that organisation membership encouraged political participation was confirmed entirely for political activities such as electoral participation and partly, for political interest (Berger et al., 2004, p. 506). For example Sam was a member of the Asia forum and had previously been a member of numerous Chinese ethnic and Asian pan-ethnic organisations. Membership in these networks appeared to encourage Sam's political interest and participation despite his disillusionment with the New Zealand government discussed in the previous section. More broadly, strong ethnic identity could best explain Patrick's electoral participation. Patrick explained that his motivation for voting in the 2014 election was to make his voice heard; in particular he identified with other Chinese migrants in New Zealand. He thought they shared a similar background and experiences as migrants in New Zealand, and he wanted to represent this part of New Zealand to the government.

Political interest could be confused or conflated with self-interest, particularly when interviewing individuals with little to no prior knowledge of such distinctions in political participation research. In the literature they are defined as distinctly different. Political interest has frequently been measured using proxies such as political conversation frequency and content, whereas selfinterest is discussed in rational choice theory and refers to interest which drives people to participate based upon an assessment of the costs and benefits of the efforts and outcomes of the voting process (Blais, 2000; Eggert \& Giugni, 2010; Goode, 1997; D. Jacobs et al., 2004). In order to mitigate potential confusion the questions regarding political conversations and political news sources were utilised in the interviews. However, self-interest could also have been identified in responses to my question regarding individual motivations for voting, or not voting, in the 2014 election.

The majority of participants did not allude directly to self-interest, however, in the same way Arnold and Holly did regarding their thoughts on motivations for 
voting. Arnold responded with reference to himself, specifically regarding the change in student allowance criteria, which could affect his ability to fund postgraduate study and formed part of his political mobilisation process which led to him voting in 2014. Regarding the motivations of her family Holly identified self-interest but with particular reference to the partisanship of her parents and of her Aunty. Holly attributed their vote choices to their own interests, specifically economic interests, when she pointed out that her parents would vote for Labour because their policies suited "working people", which she characterised her parents as. Her Aunty, however, would most likely vote for National as she owned her own business and National's policies were more oriented towards business. This is interesting in that it is similar to findings by Abramson \& Aldrich (1982) which identified declined party identification as one reasons for declining voter turnout. However, this only applied to a belief held by Holly regarding the relationship economic interests, partisanship and political participation. Therefore, this did not warrant further investigation or discussion in this study.

The social capital hypothesis, broadly speaking, predicts that social networks influence political participation (for example Armingeon \& Schädel, 2015; Cho et al., 2006a; Eggert \& Giugni, 2010; Lem, 2010). The social network-electoral participation nexus was a recurring theme throughout the analysis of these fifteen interviews. The responses of the eleven voters also indicated the influence of their social networks on their political engagement and participation. Among the New Zealand-born voters Susan, Maggie and Laurie, their friends and family also voted in the 2014 election. Of the two New Zealand-born non-voters Adrienne and Sasha, their family and friends did not vote either in 2014. As we saw with Adrienne, for example, her friends voted in the 2014 election whilst her family did not. Adrienne attributed this to her family not being particularly interested in, or aware of, political issues and the election in particular, whilst she thought her friends voted because they were interested but also because they were more informed than she was. Adrienne's other response could also be explained by the social capital hypothesis, as she also emphasised the importance of social and political context for political engagement and participation when she highlighted that among her friends she thought those who studied Commerce were more engaged than those of her 
friends who studied the Arts, who she thought did not care as much. Since Adrienne is currently studying Architecture, she most likely spends more time with the latter group of friends whose attitudes (lack of political interest) and behaviour may discourage political engagement and participation.

Susan, Maggie and Laurie all indicated the influence of their social networks on their political engagement and participation. Susan told me that listening to the views of her family and friends was part of her decision-making about who to vote for. Maggie said that the bulk of her political news is sourced from her friends who are much more politically active than she is. Laurie did not really know who to vote for and relied on her family in the decision-making process regarding who to vote for.

Participants among the $1^{\text {st }}$ generation, similarly, demonstrated that they were influenced by their social networks. Johnny's first time voting was in the 2014 election, that same year he was in the halls of residence at the University and discussed politics with many of his friends leading up to the election. Ashleigh had not felt strongly about voting in 2014 but had strongly been encouraged by her husband, Robert. Although Phoebe and Victoria were not eligible to vote in 2014 their responses indicated a positive relationship between their social networks and political interest. During her time at University, Phoebe would watch the news every evening and discuss issues, political and otherwise, with her flatmate. Phoebe also expressed a strong desire to vote in the past election despite her ineligibility. Victoria said she was more interested in international political issues rather than New Zealand specific ones, but gave an example of her friend, Shane, informing her about a march in protest of the TPPA signing; he had explained the agreement to Victoria and how it affected New Zealand specifically.

The social capital hypothesis is also relevant for explaining the correlation between social networks and electoral participation among the 1.5 generation migrant participants. Sam and Kathryn would discuss political news and issues together as well as with their friends, similar to Carol. All three also fostered their own political interests, independent of their social networks through news websites and social media, although Sam relied more so on the political organisation he is a member of, such as the Asia Forum and relied on his social 
media networks for political news and information. Holly and Arnold's social networks influence their electoral participation more directly. They live with their family and went altogether to the polling station to cast their votes at the 2014 election. Arnold also highlighted the role of his Facebook friends for sharing posts of a political nature, in particular regarding the student allowances changes in 2013, which aided in his process of political mobilisation resulting in his transition from non-voter in the 2011 election to voter in 2014.

Transnationalism, in particular transnational social networks, were a recurring theme throughout the findings. Though I did not set out to explore this concept in great depth, the recurring significance of social networks among this sample also featured the concept of transnationalism. These participants represent an increasingly transnational world where communication and transport technologies are constantly improving and are increasingly accessible. Johnny and Patrick (1 st $^{\text {sten}), ~ C a r o l ~(1.5 ~ g e n), ~ a n d ~ S u s a n ~ a n d ~ L a u r i e ~(N Z-b o r n) ~ w o u l d ~}$ travel to their, in Susan's case her father's, nation of origin annually. Holly and Arnold (1.5 gen) had travelled back to Hong Kong once or twice since migrating to New Zealand. Sam and Kathryn (1.5) no longer travelled to Taiwan, although Kathryn did when she was in school and at university, but their parent would travel to New Zealand annually to visit them. Additionally, these participants also maintained contact with these transnational networks via phone and social media. Phoebe and Victoria ( $1^{\text {st }}$ gen) also maintained contact with these networks via social media. Adrienne and Sasha did as well; however, their transnational networks had originally been established in New Zealand: that is, they were friends they had made in New Zealand and maintained contact with once their friends had emigrated. There was no link between these transnational social networks and electoral participation, although the recurrence of the theme in these findings is significant. Furthermore, it bears mentioning as an area for future research in the field of migration and political participation.

Responses among the participants in this sample indicated the significance of social groups and in particular highlighted the role of social media as a platform to garner information such as political news in addition to being introduced to and discussing political views. Participants in all three categories and from a 
range of political backgrounds identified their social networks as sources of political news, including Johnny, Sam and Maggie. Sam, specifically, uses social media to both keep in contact with his friends and as a source of political news. The role of social media among this group of voters could partly be explained by Mossberger, Tolbert, \& McNeal (2007), who found a positive relationship between online news exposure and voter turnout. Similar studies found use of social media and social networking sites such as Facebook (referred to by most of the sample in my research) for news and discussion provided an arena for individuals to explore their own opinions and beliefs and be exposed to new ideas which could consequently fuel further political interest; and encourage political engagement and political participation, both online and offline (Conroy et al., 2012; Holt et al., 2013; Vitak et al., 2011, p. 113).

Armingeon \& Schädel (2015) highlight both political elites and organisations as significant for the provision of political cues, specifically providing information that would assist in, first, the decision to vote followed by the decision for whom to cast their vote. Armingeon \& Schädel associate the decline in political participation with individualisation: "the process of individualisation leaves citizens with fewer resources in terms of cues" (2015, p. 20). The findings from this sample, however, demonstrate the role of social media as a platform upon which people can share and discuss political information and ideas, and ultimately derive political cues. This suggests the need for further research into the relationship between social networks, social media and political participation in future.

This study suggests the importance of social capital theory for understanding the electoral participation of ethnically Chinese participants in this sample. The findings align with the assertion that the role of social networks, broadly social capital, for political participation is a salient one (Armingeon \& Schädel, 2015; Putnam, 2001). Among fifteen participants, social networks had a significant effect on political interest, engagement and participation, independent of length of residence and pre-migration socialisation. In this sample, respondents' social networks provided them with political information, political cues and sounding boards with which to discuss political information and ideas. 
Putnam's (2001) argument that a positive relationship exists between social capital and political participation and the value of social networks can best explain the drivers of electoral participation among this sample. Unlike Armingeon \& Schädel's (2015) conclusion that decreasing political party membership was a driver of declining political participation, these findings suggest the importance of looking beyond traditional organisational models to consider more recent political platforms, such as social media. Overall this study has demonstrated the ongoing value of social capital theory for political participation and, specifically, for studying 1.5 generation migrant political participation as well as the benefits of utilising social networks to measure social capital.

Overall the variables utilised to measure the effects of pre- and post-migration socialisation on electoral participation of Chinese in New Zealand - length of residence and socialisation in a democratic regime versus non-democratic regime - did not affect electoral participation among this sample. Factors traditionally associated with migration could explain the electoral participation of Sam and Patrick, for example, who demonstrated a positive relationship between ethnic identity and electoral participation. However, for younger members of this group, age and life-cycle (as was the case in Buck's (2009) findings) was a prominent explanation for participants such as Sasha, who did not see how political decisions affected her life, and Arnold, who only recognised the impact political decision-making could have for him between the 2011 and 2014 elections. This suggests that the migrant experience was not significant for the electoral participation of this young Chinese cohort, although its effects may manifest later in life as was the case with Patrick (34 years) and Sam (31 years).

Demographic, social capital and identity theories have proven useful in the analysis of interviews of fifteen ethnically Chinese participants in New Zealand. Overall the median age of the group was 25 years, and both age and lifecycle combined with the influence of social networks were the most applicable for determining electoral participation among this group. Sasha and Arnold, for example, demonstrate a before and after of sorts as Sasha (22 years, undergraduate) and her friends did not see how political decisions affect their 
lives whereas Arnold (22 years, postgraduate), slightly closer to adult-life, was about to begin his career in the field he had studied, and was more aware about how political decisions affected his life. This awareness partly stemmed from his social networks who made him cognisant of these issues.

These findings suggest that overall the migrant experience had no significant effect on the electoral participation among this sample. However, for some of the older participants the migrant experience and their ethnic identity, specifically, did affect both their political engagement and participation. This suggests that demographic and social capital theory are more useful for explaining the electoral participation of younger groups at earlier stages of their life-cycle but theories of migrant political participation such as the strength of identity can help to understand the motives for political engagement and participation among older groups at later stages of their life-cycle at which time the migration experience manifests. 


\section{Conclusion}

I conclude by outlining the overarching results, highlighting two main limitations, identifying future research topics and highlighting the salience of research in the field of Chinese political participation. In this thesis I explored the effects of pre- and post-migration socialisation on the electoral participation of ethnically Chinese in New Zealand.

The initial aim of this research was to discern how pre- and post-migration socialisation affect electoral participation among Chinese in New Zealand. Literature exploring the drivers of, and barriers to, political participation of Chinese have highlighted the significance of acculturation and national origin theories as well as the persisting influence of demographic, socioeconomic and social capital theories for electoral participation among migrant and ethnic groups. In order to explore acculturation, national origin and social capital in more depth I sought to mitigate the effects of demographic and socioeconomic factors by controlling for age and education.

Through fifteen in-depth interviews with five $1^{\text {st }}$ generation migrants, five 1.5 generation migrants and five New Zealand-born participants I explored the effects of these three prominent theories of political participation: national origin, acculturation and social capital. Length of residence and socialisation in a democratic versus non-democratic regime were utilised as acculturation and national origin variables respectively. I found that among this sample of young Chinese, neither length of residence nor socialisation in a democratic versus non-democratic regime had any strong correlation with electoral participation. Demographic factors such as age and life-cycle as well as social networks and political interest were more appropriate for explaining the electoral participation among this sample. Among some older participants, also at relatively later stages of their life-cycle, their migrant status and ethnic identity played a part in mobilising them to engage and participate politically.

These findings do not suggest that pre- or post-migration socialisation do not affect electoral participation among Chinese in New Zealand. However, the results indicate, specifically, that length of residence and socialisation in a democratic versus non-democratic regime do not apply among this group. 
National origin may still be relevant for political participation, though socialisation in a democratic versus non-democratic regime is not the best measure of the merits of national origin theory. Acculturation theory is also still relevant for political participation. However, length of residence is not the best variable to employ in assessing acculturation theory.

The first limitation of these findings is that difficulties associated with regime classification may have contributed to the result. New Zealand, Taiwan, Japan and China's regime classifications were clear-cut by comparison to Hong Kong, Singapore and Malaysia which were more difficult to classify. It is therefore much easier to make predictions about and analyse the results of socialisation in New Zealand, China or Taiwan and any correlation to electoral participation, based upon Freedom House's freedom ratings and electoral process scores which I substantiated with other literature on their regime status. I classified Malaysia as democratic and both Hong Kong and Singapore as non-democratic. Despite any potential discrepancies in regime classification, socialisation in a democratic regime did not explain the electoral participation among this sample, even among those participants who had experienced socialisation in New Zealand, China and Taiwan.

Any discrepancies in these classifications, however, would not significantly affect the findings as the electoral participation among those from countries with clear-cut classifications such as China, Taiwan and New Zealand (the former non-democratic and the latter two non-democratic) confirm the finding that socialisation in democratic versus non-democratic regime did not significantly affect electoral participation among this sample..

The second limitation is the generalisability of the findings due to the small sample of participants from which the results were derived. Fifteen participants constitutes a small sample and this number is divided further: five are $1^{\text {st }}$ generation immigrants, five are 1.5 generation migrants and five are New Zealand-born. As a source of data to compare with the electoral participation of other ethnically Chinese, or to migrants from other source countries, this sample is thus limited. 
However, the depth of analysis achieved through one-on-one, in-depth interviews has resulted in interesting findings that contradict previous arguments, and other findings that align with previous research. In order to better understand migration, political socialisation and its effects on electoral participation research must endeavour to understand the people which are affected. Individual testimonies and in-depth analysis are crucial for this understanding. They help to capture real life experiences and behaviours which can then be used to explore the numerous theories regarding relationships between experience and behaviour: in this case, the relationship between migration and socialisation (experiences), and electoral participation (behaviour).

Furthermore, this research is one of only a few on the subject of ethnically Chinese electoral participation, and even more so because it utilises a New Zealand case study. This research is unique as it is one of the few to employ qualitative methods to explore Chinese electoral participation specifically, and exclusively, and the only one to do so in a New Zealand setting. I was also able to incorporate 1.5 generation migrants, who played a key role in this research. 1.5 generation migrants are another group which have received low coverage in the literature and provide an interesting subject and are unique in their experience of political socialisation in two different countries at a young age. By focusing my data collection and analysis on a sample of fifteen, ethnically Chinese individuals, I was able to explore details pertaining to their migration, socialisation and political participation experiences which may have otherwise been lost in a larger quantitative study.

This study provides a useful point of departure for future studies of Chinese political participation. Quantitative research in particular would be needed in order to test whether the explanations suggested by this research could be applied to Chinese electoral participation in the rest of New Zealand and overseas. This research has also raised more questions which a combination of both quantitative and qualitative research could seek to answer.

Future research could firstly focus on migration and political participation within specific migrant and ethnic groups. Regional groupings such as Asian and even Chinese conflates identities and does not allow for the varying 
identities, resulting from a broad range of national origins, which are products of a combination of various languages, histories, cultures and experiences, political or otherwise, to be assessed in any depth. Secondly, the significance of social capital and social networks indicates the importance of further research in the field in order to identify current and future platforms for political information, cues, engagement and participation. Thirdly, the recurring theme of transnationalism, specifically transnational social networks, throughout the interviews and findings highlights the need for further research in this area, in particular, the effects of transnationalism for social networks and for the drivers of and barriers to political participation.

It is important to understand why some migrants and ethnic groups engage and participate politically whilst others do not. In the case of New Zealand, indicators of the competence of its institutions and the overall health of its democracy lie in the political participation rates of eligible voters. More broadly, in a world of increasing mobility of people enabled by rapid technological advancement in communications and transport, understanding the effects of migration and political socialisation on electoral participation becomes increasingly salient. 


\section{Appendix 1.}

\section{Participant Information Sheet}

\section{"Chinese Political Participation"}

RESEARCHER: Ameera Clayton, School of History, Philosophy, Political Science and International Relations, Victoria University of Wellington

Project objective: I am a Masters student in Political Science at Victoria University of Wellington, New Zealand. My research project investigates the political participation of ethnically Chinese. I aim to identify potential barriers to participation and draw conclusions on the ways in which these barriers can be reduced and political participation encouraged.

My research will be sourced mainly from interviews. The data gathered will be analysed for any relationships which can be drawn between experiences of ethnically Chinese and the nature and level of political participation they engage in.

Participation: I invite you to participate in my research and share your experience.

If you agree, I will make a sound recording of the session. Information sourced from interviews will be confidential and access limited to me, my two supervisors and the transcriber. All transcribers will first sign a consent form agreeing to respect and maintain privacy of all participants involved. The written thesis will not use any names without first seeking participant permission. You may withdraw yourself (and any contributions you have made) from the study, prior to September 31, 2015. Data collection in the process of this research will be stored securely and destroyed two years subsequent to completion of the project.

The results of the research will form my thesis; be published in an academic journal; presented at an academic conference; and copies of the completed thesis deposited in the University library, and sent to the New Zealand Electoral Commission. This research has been approved by the Victoria University of Wellington Human Ethics Committee and if you have any concerns you can contact the Chair ethicsadmin@vuw.ac.nz.

Thank you for considering being a part of my research.

If you have any further questions please contact me:

Ameera.Clayton@vuw.ac.nz

Or either of my two supervisors: 
Dr Fiona Barker

School of History, Philosophy, Political Science and International Relations Victoria University of Wellington

Fiona.Barker@vuw.ac.nz

Dr Kate McMillan

School of History, Philosophy, Political Science and International Relations Victoria University of Wellington

Kate.McMillan@vuw.ac.nz 


\section{Appendix 2.}

\section{Interview Questions}

1. What is your occupation?

2. What are you studying (did you study)?

3. How old are you?

4. Tell me about your migration history, when did you or your parents (or grandparent, great grandparents) migrate to New Zealand?

5. Where do you get your political news from?

- Newspaper, friends, online news, social media

6. What do you use social media for?

7. How often do you have contact with your family and friends? By what media?

8. Are you a member of any groups?

- Sports, cultural, political, other?

9. When was the last time you spoke to family or friends about a political issue?

- Day? Weeks?

10. Did you vote in the past election and would you vote in the next election? Why or Why not?

11. Did your family and friends vote in the past election? Why? Why not?

12. What other activities do you take part in or undertake to influence politics or political decisions? -

- Protests, campaign work, petition signing, party membership

13. Are you a New Zealand citizen?

14. Do you see yourself remaining in New Zealand? (Will you apply for citizenship) Why or why not?

15. What does it mean to you to be a New Zealander?

16. What does it mean to you to be Chinese?

17. Do you consider yourself more Chinese or Kiwi? Why?

18. What does it mean to be 'Asian'?

19. Do you see yourself as 'Asian'?

20. Have you ever experienced different treatment because of your background or ethnicity, be it in school, work or elsewhere?

21. Do you maintain connections with your (or your parents') country of origin? And in what forms?

- Maintained citizenship, consider yourself Singaporean..., familial ties, friends.

22. Do you feel people like you and me can influence government decisions? Why or Why not?

- Lack of/inappropriate representation, the government doesn't pay attention. 
23. In the past election did you feel you could make an informed decision on who to vote for? Why or Why not?

- Lack of policy information, lack of information on the election process and how to vote strategically. 


\section{Bibliography}

Abramson, P. R., \& Aldrich, J. H. (1982). The Decline of Electoral Participation in America. The American Political Science Review, 76(3), 502-521. http://doi.org/10.2307/1963728

Aoki, A. L., \& Nakanishi, D. T. (2001). Asian Pacific Americans and the New Minority Politics. PS: Political Science \& Politics, (03), 605-610. http://doi.org/10.1017/S1049096501000956

Armingeon, K., \& Schädel, L. (2015). Social Inequality in Political Participation: The Dark Sides of Individualisation. West European Politics, 38(1), 1-27. http://doi.org/10.1080/01402382.2014.929341

Asia Forum. (2016). Retrieved February 27, 2016, from http://www.asiaforum.org.nz/about/

Asia New Zealand. (n.d.). Asian migration and settlement: the national context. Retrieved from http://asianz.org.nz/reports/report/asian-auckland-themultiple-meanings-of-diversity/asian-migration-and-settlement-thenational-context/

Barr, M. D. (2014). The bonsai under the banyan tree: democracy and democratisation in Singapore. Democratization, 21(1), 29-48. http://doi.org/10.1080/13510347.2012.706606

Bartley, A. (2010). 1.5 generation Asian migrants and intergenerational transnationalism: Thoughts and challenges from New Zealand. National Identities, 12(4), 381-395. http://doi.org/10.1080/14608944.2010.520976

Bartley, A., \& Spoonley, P. (2008). Intergenerational Transnationalism: 1.5 Generation Asian Migrants in New Zealand1. International Migration, 46(4), 63-84. http://doi.org/10.1111/j.1468-2435.2008.00472.x

BBC News. (2015, August 17). China explosions: What we know about what happened in Tianjin. Retrieved February 23, 2016, from http://www.bbc.com/news/world-asia-china-33844084

Berger, M., Galonska, C., \& Koopmans, R. (2004). Political integration by a detour? ethnic communities and social capital of migrants in Berlin. Journal of Ethnic and Migration Studies, 30(3), 491-507. http://doi.org/10.1080/13691830410001682052

Bueker, C. S. (2005). Political Incorporation Among Immigrants from Ten Areas of Origin: The Persistence of Source Country Effects. International Migration Review, 39(1), 103-140. http://doi.org/10.1111/j.17477379.2005.tboo257.x

Bevelander, P., \& Pendakur, R. (2009). Social capital and voting participation of immigrants and minorities in Canada. Ethnic and Racial Studies, 32(8), 1406-1430. http://doi.org/10.108o/01419870802298447

Bilodeau, A. (2008). Immigrants' Voice through Protest Politics in Canada and Australia: Assessing the Impact of Pre-Migration Political Repression. 
Journal of Ethnic and Migration Studies, 34(6), 975-1002.

http://doi.org/10.1080/13691830802211281

Bilodeau, A. (2009). Residential Segregation and the Electoral Participation of Immigrants in Australia. The International Migration Review, 43(1), 134-159.

Bilodeau, A., McAllister, I., \& Kanji, M. (2010). Adaptation to Democracy among Immigrants in Australia (L'adaptation à la démocratie chez les immigrants en Australie) (Adaptación a la democracia entre inmigrantes en Australia). International Political Science Review / Revue Internationale de Science Politique, 31(2), 141-165.

Blais, A. (2000). To Vote or Not to Vote: The Merits and Limits of Rational Choice Theory. University of Pittsburgh Press. Retrieved from http://www.jstor.org/stable/j.ctt5hjrrf

Boniface, D. S., \& Alon, I. (2010). Is Hong Kong Democratizing? Asian Survey, $50(4), 786-807$. http://doi.org/http://dx.doi.org/10.1525/as.2010.50.4.786

Brady, H. E., Verba, S., \& Schlozman, K. L. (1995). Beyond Ses: A Resource Model of Political Participation. The American Political Science Review, 89(2), 271-294. http://doi.org/10.2307/2082425

Buck, J. (2009). The Puzzle of Young Asian Political Participation: A Comparative discussion of young Asian political participation in New Zealand and the United States. University of Canterbury.

Bueker, C. S. (2005). Political Incorporation Among Immigrants from Ten Areas of Origin: The Persistence of Source Country Effects. International Migration Review, 39(1), 103-140. http://doi.org/10.1111/j.17477379.2005.tboo257.x

Cho, W. K. T. (1999). Naturalization, Socialization, Participation: Immigrants and (Non-)Voting. The Journal of Politics, 61(4), 1140-1155. http://doi.org/10.2307/2647557

Cho, W. K. T., Gimpel, J. G., \& Dyck, J. J. (2006). Residential Concentration, Political Socialization, and Voter Turnout. The Journal of Politics, 68(1), 156-167. http://doi.org/10.1111/j.1468-2508.2006.00377.x

Cho, W. K. T., Gimpel, J. G., \& Wu, T. (2006). Clarifying the Role of SES in Political Participation: Policy Threat and Arab American Mobilization. Journal of Politics, 68(4), 977-991. http://doi.org/10.1111/j.14682508.2006.00482.x

Coleman, J. (1988). Social Capital in Creaton of Human Capital. American Journal of Sociology, 94, 95-120.

Conroy, M., Feezell, J. T., \& Guerrero, M. (2012). Facebook and political engagement: A study of online political group membership and offline political engagement. Computers in Human Behavior, 28(5), 1535-1546. http://doi.org/10.1016/j.chb.2012.03.012

Deth, J. W. van. (1990). Interest in Politics. In M. K. Jennings \& J. W. van Deth (Eds.), Continuities in Political Action: A Longitudinal Study of Political 
Orientations in Three Western Democracies. New York: De Gruyter and Aldine.

Eggert, N., \& Giugni, M. (2010). Does Associational Involvement Spur Political Integration? Political Interest and Participation of Three Immigrant Groups in Zurich. Swiss Political Science Review, 16(2), 175-210. http://doi.org/10.1002/j.1662-6370.2010.tbo0157.x

Electoral Commission. (2014). Your vote is a powerful thing. Retrieved February 23, 2016, from http://www.elections.org.nz/events/2014general-election/campaigns-and-resources-2014/your-vote-powerfulthing

Electoral Commission. (2015). Who can and can't enrol? Retrieved February 23, 2016, from http://www.elections.org.nz/voters/enrol-check-or-updatenow/who-can-and-cant-enrol

Fennema, M., \& Tillie, J. (1999). Political participation and political trust in Amsterdam: Civic communities and ethnic networks. Journal of Ethnic and Migration Studies, 25(4), 703-726. http://doi.org/10.1080/1369183X.1999.9976711

Freedom House. (2016). Freedom in the World 2016. Retrieved from freedomhouse.org/report/freedom-world-2016/table-scores . (2015). Freedom in the World: China. Retrieved from freedomhouse.org/report/freedom-world/2015/china . (2015). Freedom in the World: Hong Kong. Retrieved from freedomhouse.org/report/freedom-world/2015/hong-kong . (2002). Freedom in the World: Hong Kong. Retrieved from freedomhouse.org/report/freedom-world/2002/hong-kong . (2015). Freedom in the World: Japan. Retrieved from freedomhouse.org/report/freedom-world/2015/japan . (2015). Freedom in the World: Malaysia. Retrieved from freedomhouse.org/report/freedom-world/2015/malaysia . (2015). Freedom in the World: New Zealand. Retrieved from freedomhouse.org/report/freedom-world/2015/new-zealand . (2015). Freedom in the World: Singapore. Retrieved from freedomhouse.org/report/freedom-world/2015/Singapore . (2015). Freedom in the World: Taiwan. Retrieved from freedomhouse.org/report/freedom-world/2015/taiwan

Gimpe, J., Lay, J., \& Schuknecht, J. (2003). Cultivating Democracy: Civic Environments and Political Socialization in America. Brookings Institution Press.

Glick Schiller, N., \& Basch, L. (1995). From Immigrant to Transmigrant: Theorizing Transnational Migration. Anthropological Quarterly, 68(1), 48-63.

Goode, W. J. (1997). Rational Choice Theory. The American Sociologist, 28(2), 22-41. 
Henderson, A. (2003). Untapped Talents. In M. Ip, Unfolding History. Auckland University Press.

Henderson, A. (2013). Immigrants and Electoral Enrolment: Do the numbers add up? (Working Paper No. 13-01) (pp. 1-35). Statistics New Zealand. Retrieved from http://www.stats.govt.nz/methods/researchpapers/working-papers-original/immigrants-electoral-enrolment-1301.aspx

Henn, M., \& Foard, N. (2012). Young People, Political Participation and Trust in Britain. Parliamentary Affairs, 65(1), 47-67. http://doi.org/10.1093/pa/gsro46

Hennink, M. M. (2011). Qualitative research methods / by Monique Hennink, Inge Hutter, Ajay Bailey. Los Angeles, Calif; London: SAGE.

Holt, K., Shehata, A., Strömbäck, J., \& Ljungberg, E. (2013). Age and the effects of news media attention and social media use on political interest and participation: Do social media function as leveller? European Journal of Communication, 28(1), 19-34. http://doi.org/10.1177/0267323112465369

Hopkin, J. (2010). The Comparative Method. In D. Marsh \& G. Stoker (Eds.), Theory and Methods in Political Science. Basingstoke: Palgrave Macmillan.

Ip, M. (2015). Chinese [Web page]. Retrieved January 6, 2016, from http://www.teara.govt.nz/en/chinese

Jacobs, D., Phalet, K., \& Swyngedouw, M. (2004). Associational membership and political involvement among ethnic minority groups in Brussels. Journal of Ethnic and Migration Studies, 3o(3), 543-559. http://doi.org/10.1080/13691830410001682089

Jacobs, D., \& Tillie, J. (2004). Introduction: social capital and political integration of migrants. Journal of Ethnic and Migration Studies, 3O(3), 419-427. http://doi.org/10.1080/13691830410001682016

Jacobs, J. (1961). The Death and Life of Great American Cities. New York: Random House.

Jedwab, J. (2006). CAPITAL PARADOXES: Has Robert Putnam Erred on Ethnicity, Engagement and Trust? Canadian Issues, 65-67.

Kriesi, H. (2008). Political Mobilisation, Political Participation and the Power of the Vote. West European Politics, 31(1-2), 147-168.

http://doi.org/10.1080/01402380701834762

Kuerban, A. (2005). National origin diversity of foreign-born Asian immigrants voter turnout in 2000 (Ph.D.). Fordham University, United States -- New York. Retrieved from http://search.proquest.com/docview/304997536/abstract/B16DFBEB12 CD488CPQ/1?accountid=14782

Lapp, M. (1999). Ethnic group leaders and the mobilisation of voter turnout: Evidence from five Montreal communities. Canadian Ethnic Studies, 31(2), 17-42. 
Langton, K. P. (1969). Political socialization. New York, Oxford University Press.

Leighley, J. E. (1995). Attitudes, Opportunities and Incentives: A Field Essay on Political Participation. Political Research Quarterly, 48(1), 181-209. http://doi.org/10.2307/449127

Lem, W. (2010). Mobilization and disengagement: Chinese migrant entrepreneurs in urban France. Ethnic and Racial Studies, 33(1), 92-107. http://doi.org/10.108o/01419870903023678

Lien, P. (1994). Ethnicity and Political Participation: A Comparison between Asian and Mexican Americans. Political Behavior, 16(2), 237-264.

Lien, P. (2010). Pre-emigration Socialization, Transnational Ties, and Political Participation Across the Pacific: A Comparison Among Immigrants from China, Taiwan, and Hong Kong. Journal of East Asian Studies, 1O(3), $453-482,521$.

Loury, G. (1977). A Dynamic Theory of Racial Income Differences. In P. Wallace \& A. LeMund (Eds.), Women, Minorities and Employment Discrimination (pp. 153-188). Lexington, Mass.: Lexington Books.

Maxwell, R. (2010). Political Participation in France among Non-EuropeanOrigin Migrants: Segregation or Integration? Journal of Ethnic and Migration Studies, 36(3), 425-443. http://doi.org/10.1080/13691830903471537

Mayer, A. K. (2011). Does Education Increase Political Participation? Journal of Politics, 73(3), 633-645. http://doi.org/10.1017/So02238161100034X

McAllister, I., \& Makkai, T. (1992). Resource and Social Learning Theories of Political Participation: Ethnic Patterns in Australia. Canadian Journal of Political Science/Revue Canadienne de Science Politique, 25(02), 269293. http://doi.org/10.1017/Sooo842390000398X

McGrath, T., Butcher, A., Pickering, J., \& Smith, H. (2005b). Engaging Asian Communities in New Zealand (Asian Communities). Asia New Zealand Foundation.

Michelson, M. R. (2003). The Corrosive Effect of Acculturation: How Mexican Americans Lose Political Trust*. Social Science Quarterly, 84(4), 918933. http://doi.org/10.1046/j.0038-4941.2003.08404017.x

Ministry of Business, Innovation \& Employment - Hīkina Whakatutuki. (2014). Migration Trends and Key Indicators.

Mossberger, K., Tolbert, C. J., \& McNeal, R. S. (2007). Digital Citizenship : The Internet, Society, and Participation. Cambridge, MA, USA: MIT Press. Retrieved from http://site.ebrary.com/lib/alltitles/docDetail.action?docID=10194164

Mulgan, R. G. (1997). Politics in New Zealand (2nd ed). Auckland, N.Z: Auckland University Press.

Nakash, O., Nagar, M., Shoshani, A., Zubida, H., \& Harper, R. A. (2012). The effect of acculturation and discrimination on mental health symptoms and risk behaviors among adolescent migrants in Israel. Cultural Diversity 
and Ethnic Minority Psychology, 18(3), 228-238.

http://doi.org/http://dx.doi.org/10.1037/a0027659

Nationality Law of the People's Republic of China (1980).

New Zealand Immigration Service. (1994). New Zealand Immigration Fact Pack. Wellington: Department of Labour.

Ng, J. (2001). Chinese settlement in New Zealand, past and present: Ng Fon and his family in New Zealand. Dunedin, N.Z.: Amity Centre Publishing Project.

Ng, S. H., Liu, J. H., Loong, C., \& Weatherall, A. (1999). Links across generations among New Zealand Chinese. Wellington, N.Z.: School of Psychology, Victoria University of Wellington.

Oh, S., \& Min, P. G. (2011). Generation and Earnings Patterns Among Chinese, Filipino, and Korean Americans in New York. International Migration Review, 45(4), 852-871. http://doi.org/10.1111/j.1747-7379.2011.00870.x

Pang, D. (2003). Education, Politics and Chinese New Zealander Identities. In M. Ip (Ed.), Unfolding history, evolving identity : the Chinese in New Zealand / edited by Manying Ip. Auckland, NZ: Auckland University Press.

Park, S.-J. (2006). Political participation of "Asian" New Zealanders: A case study of ethnic Chinese and Korean New Zealanders (Ph.D.). The University of Auckland (New Zealand), New Zealand. Retrieved from http://search.proquest.com/docview/304983532/abstract?accountid=147 82

Parliamentary Library. (2015, February 12). National Party. Retrieved February 25, 2016, from http://www.parliament.nz/en$\mathrm{nz} / \mathrm{mpp} /$ parties/national/ooPlibMPPNational1/national-party

Pasek, J., Kenski, K., Romer, D., \& Jamieson, K. H. (2006). America's Youth and Community Engagement How Use of Mass Media Is Related to Civic Activity and Political Awareness in 14- to 22-Year-Olds. Communication Research, 33(3), 115-135. http://doi.org/10.1177/0093650206287073

Però, D. (2008). Political engagement of Latin Americans in the UK: Issues, strategies, and the public debate. Focaal, 2008(51), 73-90.

Putnam, R., D. (2001). Bowling alone : the collapse and revival of American community. London: Simon \& Schuster.

Quintelier, E. (2009). The Political Participation of Immigrant Youth in Belgium. Journal of Ethnic and Migration Studies, 35(6), 919-937. http://doi.org/10.1080/13691830902957700

Radio New Zealand. (2014, September 7). Most unregistered voters under 30. Retrieved February 23, 2016, from http://www.radionz.co.nz/news/political/253967/most-unregisteredvoters-under-30

Ramakrishnan, S. K. (2005). Democracy in immigrant America: Changing Demogaphics and Political Participation. Stanford C.A.: Stanford University Press. 
Richman, K. (1992). A Lavalas at home/a Lavalas for home: inflections of transnationalism in the discourse of Haitian president Aristide. Annals of the New York Academy of Sciences, 645, 189-200.

Rios, P. (1992). Comments on rethinking migration: a transnational perspective. Annals of the New York Academy of Sciences, 645, 225-229.

Robertson, E. (2015, September 4). Why are the baby boomers desperate to make millennials hate ourselves? The Guardian. Retrieved from http://www.theguardian.com/commentisfree/2015/sep/o4/why-are-thebaby-boomers-desperate-to-make-us-millennials-hateourselves?CMP=soc_567

Rolfe, M. (2004). Interrogating the Usual Suspects: Education and Voter Turnout. Annual Meeting of the Midwest Political Science Association.

Rosenstone, S. J. (1993). Mobilization, participation, and democracy in America. New York: Macmillan.

Seeley, J., Sim, A., \& Loosley, E. (1956). Crestwood Heights: A Study of the Culture of Suburban Life. New York: Basic Books.

Statistics New Zealand. (2004). Review of the Measurement of Ethnicity June 2004. Wellington.

Statistics New Zealand. (2016). Population projections overview. Retrieved February 28, 2016, from

http://www.stats.govt.nz/browse_for_stats/population/estimates_and_p rojections/projections-overview/nat-asian-proj.aspx

Sweeny, P., \& Lu, J. (2015, August 11). China devaluation sparks fear of currency war, angers U.S. lawmakers. Reuters. Retrieved from http://www.reuters.com/article/us-china-markets-yuanidUSKCNoQG04U20150811

TNS New Zealand. (2014). Voter and Non-Voter Satisfaction Survey 2014. The Electoral Commission. Retrieved from http://www.elections.org.nz/events/2014-general-election/electionresults-and-reporting/voter-and-non-voter-satisfaction-survey

Tossutti, L. (2005). ELECTORAL TURNOUT AND CANADA'S CHANGING CULTURAL MAKEUP: Interviews with Three Municipal Leaders. Canadian Issues, 53-56.

Uhlaner, C. J., Cain, B. E., \& Kiewiet, D. R. (1989). Political Participation of Ethnic Minorities in the 1980s. Political Behavior, 11(3), 195-231.

Verba, S. (1995). Voice and equality : civic voluntarism in American politics. Cambridge, Mass: Harvard University Press.

Verba, S., \& Nie. (1972). Participation in America: political democracy and social equality. New York, Harper \& Row.

Vitak, J., Zube, P., Smock, A., Carr, C. T., Ellison, N., \& Lampe, C. (2011). It's Complicated: Facebook Users' Political Participation in the 2008 Election. CyberPsychology, Behavior \& Social Networking, 14(3), 107-114. http://doi.org/10.1089/cyber.2009.0226 
Wengraf, T. (2001). Qualitative Research Interviewing. 1 Oliver's Yard, 55 City Road, London England EC1Y 1SP United Kingdom: SAGE Publications, Ltd. Retrieved from http://srmo.sagepub.com/view/qualitative-researchinterviewing/SAGE.xml

Whiteley, P. F., \& Seyd, P. (2002). High-intensity participation: The dynamics of party activism in Britain. Michigan: The University of Michigan Press.

White, S., Nevitte, N., Blais, A., Everitt, J., Fourmier, J., \& Gidengil, E. (2006). Making up for lost time: immigrant voter turnout in Canada. Electoral Insight, 8(2), 10-16.

Wong, L. L. (2007). Transnationalism, active citizenship, and belonging in Canada. International Journal, 63(1), 79-99.

Wong, J. S., Lien, P.-T., \& Conway, M. M. (2005). Group-Based Resources and Political Participation among Asian Americans. American Politics Research, 33(4), 545-576. http://doi.org/10.1177/1532673Xo4270521 